\title{
ESTUDO DO COMPORTAMENTO DA BROCA DA BANANEIRA Oasmopolites sordidus (GERMAR, 1824) (COLEOPTERA: CURCULIONIDAE), VISANDO AO SEU CONTROLE
}

\author{
CLELMA GOMES SILVA
}

Orientador: Prof. Dr. OCTÁVIO NAKANO

Tese apresentada à Escola Superior de Agricultura "Luiz de Queiroz", da Universidade de São Paulo, para obtenção do título de Doutor em Ciências. Área de Concentração: Entomologia.

PIRACICABA

Estado de São Paulo - Brasil Junho, 1985 
ii.

Aos meus pais, irmãos, primos e tios, a minha gratidão

Ao meu filho Ewerton Lamarck

DEDICO 


\section{AGRADEC IMENTOS}

- Ao Prof. Dr. Octávio Nakano, pela constante orientação, apoio e estímulo no decorrer da presente pesqui sa.

- Aos Professores do Departamento de Entomolo gia da Escola Superior de Agricultura "Luiz de Queiroz" da Universidade de São Paulo, pela amizade e consideração.

- Ao Prof. Dr. Evoneo Berti Filho, pela versão do resumo para o inglês.

- Ao Estagiārio Carlos Eduardo Masis Chacōn, pela colaboração nos trabalhos de campo e laboratório.

- As Bibliotecārias e demais funcionārios da Biblioteca Central pela cortesia e gentileza no atendimento.

- Aos funcionārios do Departamento de Entomologia, desta Escola.

- As Irmãs Aparecida do Carmo Santos, Socorro Gomes da Silva e Srta. Celina Mendes Mello, do Pensionato Imaculada Conceição, pela carinhosa acolhida.

- Aos Colegas do Departamento de Fitotecnia do Centro de Ciências Agrärias da Universidade Federal da Paraíba, pela licença concedida para a realização deste trabalho. 


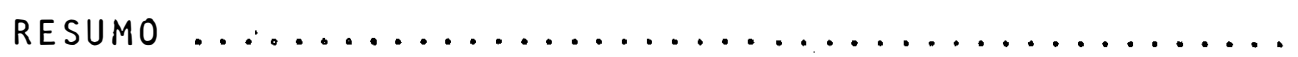

1. INTRODUÇAOO .........................

2. REVISÁO DE LITERATURA ................. 3

2.1. Histórico, sononímia e distribuição geográfica $\ldots \ldots \ldots \ldots \ldots \ldots \ldots \ldots \ldots \ldots \ldots \ldots \ldots \ldots \ldots \ldots \ldots \ldots$

2.2. Plantas hospedeiras e suscetibilidade ao ataque $\ldots \ldots \ldots \ldots \ldots \ldots \ldots \ldots \ldots \ldots \ldots \ldots \ldots \ldots \ldots \ldots \ldots \ldots \ldots$

2.3. Aspectos biológicos, morfológicos e etológ

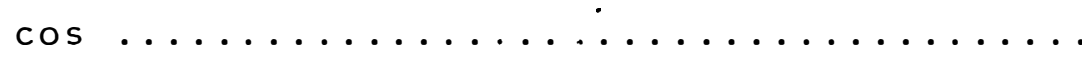

2.4. Sintomas de ataque, prejuízos e técnicas de captura $\ldots \ldots \ldots \ldots \ldots \ldots \ldots \ldots \ldots$

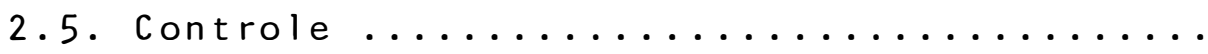

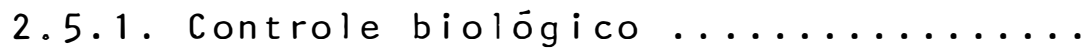

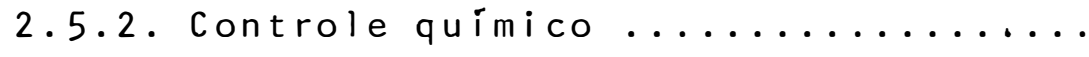

2.5.3. Quimioesterilizantes .......... 16

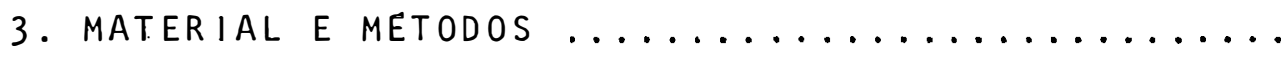

3.1. Comportamento da broca da bananeira Cosmopo

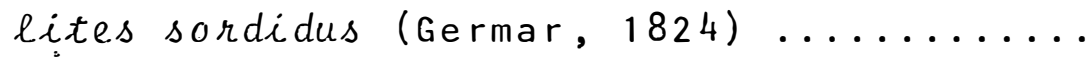

3.1.1. Preferéncia pelo local e idade da planta $\ldots \ldots \ldots \ldots \ldots \ldots \ldots \ldots \ldots \ldots \ldots \ldots \ldots$

3.1.2. Teste de substâncias no aumento da

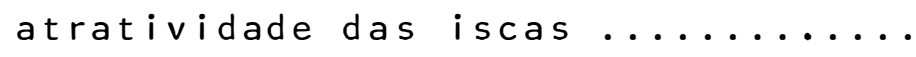




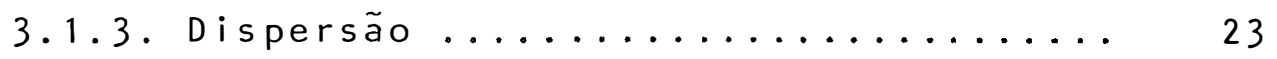

3.1.4. Influência da temperatura sobre a dis

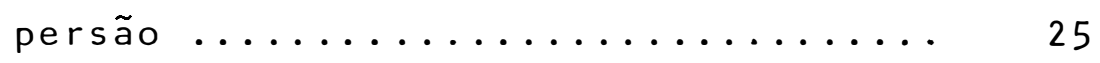

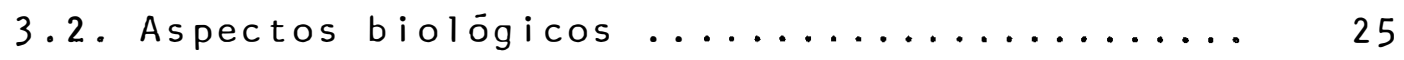

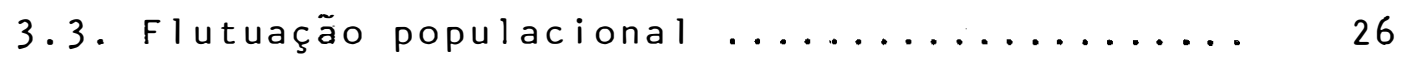

3.4. Patogenicidade do fungo Beauveria bassiana

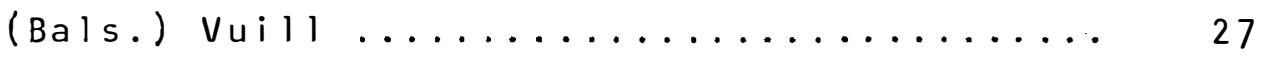

3.4 .1 . Patōgeno $\ldots \ldots \ldots \ldots \ldots \ldots \ldots \ldots \ldots \ldots \ldots$

3.4.1.1. Meio de cultura .......... 28

3.4.1.2. Quantificação e viabilidade do inciculo .............. 28

3.4.1.3. Inseto-teste ........... 29

3.5. Controle químico ................. 30

3.5.1. Estudo comparativo de inseticidas clo rados e carbamatos na atratividade de

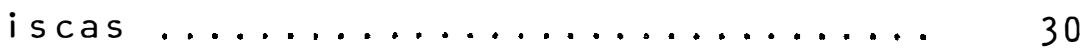

3.5.2. Uso de quimioesterilizante ........ 31

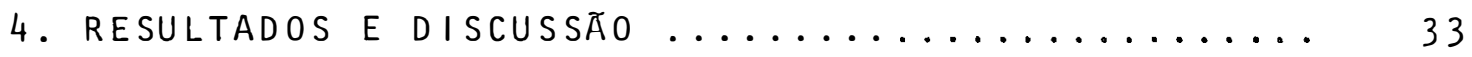

4.1. Comportamento da broca da bananeira C. sordi dus em presença de pseudocaule e rizoma .... 33

4.1.1. Atratividade ................ 33

4.1.2. Substäncias para aumento da atratividade das iscas ............... 37

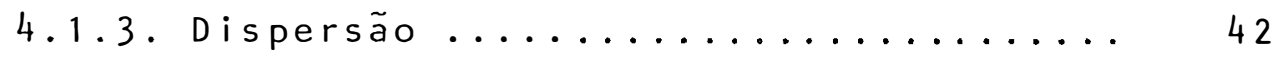


4.1.4. Influência da temperatura na dipersão de C. sordidus ............ 45

4.2. Aspectos biológicos .............. 48

4.3. Flutuação populacional ............. 50

4.3.1. Parasitismo natural .......... 55

4.4. Patogenicidade de $B$. bassiana em adultos de C. sordidus ................... 55

4.5. Controle químico ................. 59

4.5.1. Estudo comparativo entre produtos clorados e carbamatos .......... 59

4.5.2. Uso de quimioesterilizantes ...... 64

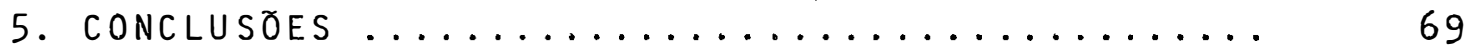

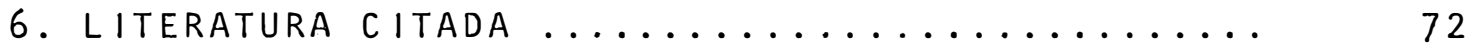




\author{
ESTUDO DO COMPORTAMENTO DA BROCA DA BANANEIRA, \\ Cosmopolites sondidus (Germar, 1824) (Coleoptera: \\ Curculionidae), VISANDO AO SEU CONTROLE
}

Autora: CLELMA GOMES SILVA

Orientador: Prof. Dr. OCTAVIO NAKANO

\title{
REsUMO
}

A broca da bananeira Cosmopolites sordidus (Germar, 1824) é a praga mais importante da cultura. Em vir tude da necessidade de melhores conhecimentos bäsicos sobre este inseto realizaram-se estudos sobre o seu comportamento para um controle mais eficiente.

A pesquisa foi conduzida em laboratório e cam po do Departamento de Entomologia da Escola superior de Agri cultura "Luiz de Queiroz", da Universidade de São Paulo no ano de 1983 e no Departamento de Fitotecnia do Centro de Ciên cias Agrārias da Universidade Federal da Paraíba no ano de 1984.

Pelos resultados obtidos, verificou-se que a alimentação normal dos adultos de $C$. sordidus se constitui tanto de pseudocaule como rizoma, não diferindo quanto a atratividade; e que o uso de álcool e melaço em diferentes 
concentrações não aumentam esta atratividade.

os insetos são sedentārios e sua movimentação dä-se por caminhamento e apresentam um termopreferendo entre 20 e $30^{\circ} \mathrm{C}$.

Os dados biológicos obtidos sob condições de laboratório, foram os seguintes: incubação variou entre 3 a 12 dias e em média $6,94 \pm 0,63$ dias; período larval de 22 a 30 dias e em média $27,40 \pm 0,81$ dias e o período pupal variou de 9 a 11 dias e em média $10,33 \pm 0,67$ dias.

Quanto ao contrôle químico, verificou-se que - aldicarb e carbofuran foram os mais eficientes, seguido do bendiocarb.

Testada a ação esterilizante de alguns produtos, através do preparo dos ingredientes ativos por litro de ägua o diflubenzuron $25 \%$ PM $(1,25 \mathrm{~g}$ e $5,00 \mathrm{~g})$ e o oxicloreto de cobre $50 \%$ PM $(20,00 \mathrm{~g})$ conferiram inibição da eclosão de larvas de $C$. sordidus, o mesmo registrado para o avermectin $1,8 \% \mathrm{~s}$ na dosagem $5,6 \mathrm{ml}$.

Em relação a flutuação populacional da broca, constatou-se que os meses de setembro e dezembro foram os de. maior atividade, no município de Areia - PB.

Verificou-se, também, a patogenicidade de Beauveria bassiana (Bals) Vuill, com percentagem de parasi- 
. ix.

tismo natural de $0,97 \%$, o que demonstra a viabilidade da ut lização deste agente atravēs de um programa de controle inte grado. 
STUDY OF THE BEHAVIOUR OF THE BANANA ROOT BORER, Cosmopolites sordidus (Germar, 1824) (Coleoptera:

Curculionidae) AIMING AT ITS CONTROL

\author{
Author: CLELMA GOMES SILVA \\ Adviser: Prof. Dr. OC.TÁVIO NAKANO
}

\title{
SUMMARY
}

This research deals with the study of the behaviour of Cosmopolites sordidus (Germar, 1824) a iming at its control. The experiments were set in laboratory and in the field of the Department of Entomology of "Escola Superior de Agricultura Luiz de Queiroz" University of São Paulo, in Piracicaba, State of São Paulo, and of the Department of Plant Technology of the "Centro de Ciências Agrārias", University of Paraiba, in Areia, State of Paraiba, Brazil. The results have indicated that $C$. sordidus showed no difference as to the attractiveness to feed on pseudostem or rhizome. Also the mixture of alcohol and molasses, at different concentrations, do not increase this attractiveness. The insects are sedentary, move by walking and have a thermal preferendum between $20^{\circ}$ and $30^{\circ} \mathrm{C}$. The biological data obtained in laboratory conditions were as 
follow: egg period ranged from 3 to 12 days, with a mean of $6.94 \pm 0.63$ days; larval period ranged from 22 to 30 days, with a mean of $27.40 \pm 0,81$ days, and pupal period ranged from 9 to 11 days, with a mean of $10.33 \pm 0,67$ days. The most efficient insecticides to control the banana root borer were aldicarb and carbofuran, followed by bendiocarb. The sterilizing products diflubenzuron $25 \%$ WP $(1.25 \mathrm{~g}$ and $5.00 \mathrm{~g})$ and Copper 0xychlorid $50 \%$ WP $(20.00 \mathrm{~g})$ have inhibited the hatching of $C$. sordidus larval, the same occuring for Avermectin $1.8 \% \mathrm{~s}(5.6 \mathrm{ml})$. Concerning the fluctuation population of the borer the highest peaks of activity were in september and in december, in Areia, State of Paraiba. The percentage of parasitism $(0.97 \%)$ of Beauveria bassiana (Bals) vuill found in this research demonstrates that this pathogen may be'used in the programs control of the banana root borer. 


\section{INTRODUÇÃO}

No Brasil, o cultivo de banana acha-se difundido em todo território nacional o que representa meio de subsistência para populações rurais das vārias regiões brasi leiras; além disso essa cultura, ocupa papel de destaque como produto de exportação.

A produção brasileira está concentrada nas re giões Nordeste e Sudeste, assegurando ao Brasil o 1 ? lugar como produtor mundial (EMBRAPA, 1984).

Contudo, os problemas fitossanitārios que a afetam são de grande importância, destacando-se entre eles a broca da bananeira Cosmopolites sordidus (Germar, 1824) que tem prejudicado de forma significativa a produtividade da ba naneira. 
.2 .

Considerando-se o valor econômico da cultura e os prejuízos causados por esta praga, conduziu-se a presen te pesquisa com o objetivo de se conseguir subsídios para o conhecimento do seu comportamento e através disso, meios mais adequados ao seu contrôle. 


\title{
2. RevisÃo de Literatura
}

2.1. Histōrico, sinonimia, distribuição geogrāfica

\begin{abstract}
A broca ou moleque da bananeira foi descrita por Germar em 1824 como pertencente ao gênero Calandra. Pos teriormente recebeu as denominações Sphenophorus sordidus (Germar, 1824), Sphenophorus liratus Gyllenhal, 1838 e Sphenophorus striatus Fahraeus, 1845 (SARAIVA, 1964 e BECCARI, 1967 a)
\end{abstract}

Em 1885, Chevrolat criou o gênero Cosmopolites, com a espécie sordidus transferida para esse gẹnero, sendo conhecida atualmente como Cosmopolites sordidus (Germar, 1824)(SARAIVA, 1964). 
Este inseto é nativo do sudeste de Āsia e seu centro de origem encontra-se provavelmente na região Malásia - Java-Bornēu (CUILLE, 1950 e SIMMONDS, 1973).

Para CUILLE (1950), SIMMONDS (1966) e FEAKIN (1975); a praga encontra*se distribuída nas Américas, África, Asia, Austrälia e 0ceania. Montellano (1954), citado por ARLEU (1982), registrou que sua distribuição no mundo está compreendida nas regiões tropicais e subtropicais, contudo FonSECA (1936) e BECCARI (1967b) afi rmaram que o inseto acha-se difundido em tôdas as regiões onde se cultiva banana.

2.2. Plantas hospedeiras e suscetibilidade ao ataque

Em relação às plantas hospedeiras, ROBERTS (1955), registrou sua ocorrência em banana, abacá e ocasiona mente em cana-de-açúcar. Contudo, CHAMPION (1968) refere-se a praga como específica dos gênerosMusa e Enseto, enquanto SA RAIVA (1964) e SIMMONDS (1973) relataram que o inseto ataca somente plantas do gênero Musa.

Por outro lado, parece não haver entre as espécies e variedades cultivadas, nenhuma que se possa conside rar resistente à praga; contudo hà diferenças consideräveis quanto à suscetibilidade ao ataque (SARAIVA, 1964 e SIMMONDS, 1973). 
Trabalhos conduzidos por HORD e FLIPPIN (1956) em Honduras, indicaram que a variedade Gros Michel é mais sus cetivel que a Bout Rond (provavelmente Lacatan).

No Brasil, MOREIRA (1971) estabeleceu uma escala de preferência à praga onde observou que as cultivares Maçã e Terra são mais atacadas que a Prata, Nanica e Nanição, enquanto NOGUEIRA (1977) constatou que rizomas de Nanica e Maçã são mais atrativos.

ZEM et alii (1978) baseando-se no comportamen to de cultivares à ataque da broca, verificaram que as cultivares Robusta, Leite e Pachá apresentaram os menores indices de infestação que as cultivares Figo Cinza, Figo VermeIho, Nanica, Terra e Maçã, enquanto MESQUITA et alii (1984) relataram que as cultivares Nanica e Leite são mais suscetíveis que as cultivares Figo Vermelho e ouro.

\subsection{Aspectos Biológicos, Morfológicos e Etológicos}

A broca da bananeira Cosmopolites sordidus (Germar, 1824) vive no interior ou a volta da bananeira.

Os ovos são postos isolados na base do pseudo caule, no ponto de inserção das bainhas das fôlhas, em orifí cios praticados pela fêmea com o rostro (FONSECA, 1936, SARAIVA, 1964 e SCHMIDT, 1965). 
.6 .

A incubação dos ovos dä-se entre 5 e 8 dias (FONSECA, 1936 e ROBERTS, 1955).

Segundo CUILLE (1950), uma fêmea coloca, em média 4,8 ovos por mês, estando a capacidade de oviposição em função da temperatura, alimentação e efeito de grupo.

As. larvas são brancas, ápodas e quando comple tamente desenvolvidas medem aproximadamente 11 a $12 \mathrm{~mm}$ de comprimento. Findo o período larval, que varia de 12 a 22 dias, segundo FONSECA (1936), no Brasil; 15 a 21 dias, em Honduras (ROBERTS, 1955), 12 a 24 dias em São Tomé (SARAIVA, 1964), as larvas aproximam-se do exterior do rizoma e aí se imobilizam, tendo previamente aberto uma câmara oval, fechada do lado exterior por um tampão de fibras onde se transfor mam em pupas. Nessa fase, LONGORIA (1975) observou dimorfís mo sexual, através do 9 ? esternito abdominal.

Em relação à duração desse período, FONSECA (1936) e ROBERTS (1955) registraram uma duração de 6 a 10 e 5 a 7 dias, respectivamente.

Quanto ao ciclo biológico do C. sordidus, este varia segundo as condições ambientais. CUILLE (1950) observou uma duração média de 61,7 dias, com um mínimo de 24 e máximo de 220 dias.

0 inseto adulto ē de côr preta uniforme, ten- 
do quase todo o prōtorax, cabeça, rostro e os apêndices pontuados. Os.ëlitros são estriados longitudinalmente, tendo cada estria uma sērie de pontuações (FONSECA, 1936 e Seabra, 1.922, citado por SCHMIDT, 1965).

0 sexo, nos adultos pode ser distinguido pela inclinação do ültimo esternito abdominal, sendo este muito inclinado nos machos, fato que não ocorre entre as fêmeas (ROTH,e WILLIS, 1963); entretanto,BECCARI (1967a) relatou que esta particularidade nem sempre é facilmente interpretada, devido a mobilidade do segmento que pode provocar variações no ângulo e que nas fêmeas não fecundadas o ângulo é di ficil de ser notado.

Quanto aos häbitos, FONSECA (1936), CUILLE (1950) e SARAIVA (1964) relataram que o inseto é noctivago e hidrófilo. Durante o dia, permanecem imóveis, abrigados nas touceiras (dentro das bainhas das fôlhas e cascas caídas e restos da cultura).

Pesquisas conduzidas por ROTH e WILLIS (1963) registraram que machos e fêmeas respondem diferentemente a um mesmo gradiente de umidade e que o preferendo dos machos é menor que o das fêmeas.

De acordo com CUILLE (1950), a luminosidade provoca fortes perturbações sobre a atividade da praga. Por outro lado, à temperatura de $25^{\circ} \mathrm{C}$, no escuro, verificou que 
o inseto consegue caminhar $1,04 \mathrm{~m}$ por noite.

Wallace (1938), citado por CUILLE (1950), empregando 'a técnica de marcação e recaptura de insetos onde foram marcados dois grupos de insetos e liberados em touceiras de bananeira, verificou que no 21 ? dia apōs a marcação e liberação, o inseto mais afastado achava-se a $21 \mathrm{~m}$ concluindo que o inseto pouco se afasta do seu habitat.

Estudos relativos a quimiotropismo de C. sordidus mostraram que o inseto responde positivamente a mistura de ālcool etílico e extrato etéreo de rizoma (CUILLE, 1950). Por outro lado, pesquisas de NOGUEIRA (1975) sobre o uso de substâncias no aumento da atratividade de iscas, em condições de campo não registraram aumento no número de inse tos quando as iscas foram tratadas com os álcoois etílico, metílico e isoamílico e o éster acetato de butila.

Quanto à movimentação do inseto e sua correla ção com fatóres climāticos, MARTINEZ (1971), no vale do Ribeira, em São Paulo, assinalou que a maior movimentação ocor reu no período de novembro a abril, enquanto OLIVEIRA et alii (1976), em Angra dos Reis, no Rio de Janeiro, verificaram que o pico populacional da praga ocorreu em setembro e agosto a setembro nos bananais da cultivar Prata, localizados respectivamente na várzea e encosta, não registrando influência dos fatores climáticos na flutuação da praga. 
Contudo, ZEM e ALVES (1979a) assinalaram uma movimentạção uniforme durante todo o ano e um decréscimo da população no período chuvoso, para as condições da Bahia,con firmados por VEIGA et alii (1981), em Pernambuco, onde consta taram uma maior movimentação do inseto, nos mêses secos (setembro e outubro).

No Estado do Espírito Santo, ARLEU (1982) encontrou uma movimentação uniforme durante todo o ano assinalando pouca influência dos elementos climäticos sobre a popu lação da praga.

2.4. Sintomas de ataque, prejuizzos e técnicas de captura Inūmeros são os trabalhos existentes relatando os danos causados pela broca.

De acordo com FONSECA (1936), as primeiras manifestações de ataque se caracterizam externamente pelo aspecto das plantas cujas fölhas amarelecem e os cachos tornam -se reduzidos.

As larvas, ao broquearem o rizoma causam danos diretos, pela destruição dos tecidos, sobretudo dos vasos libero lenhosos enquanto que os danos indiretos resultam da sucessão de outros parasitos e moléstias, que infectamo rizoma . 
Quanto aos prejuizos causados, estima-se que em Honduras haja uma redução de $25,8 \%$ e $7,81 \%$ para plantações com, 40 mêses e 28 mêses de idade, respectivamente (R0BERTS, 1955).

No Brasil, calcula-se uma redução na produção de cerca de $30 \%$ devido ao ataque da broca (MOREIRA, 1971 e EMBRAPA, $1984^{\prime}$ )。

A técnica de captura de adultos de C.sordidus atravës de iscas de pseudocaules e rizomas, numa tentativa de se quantificar o nível de infestação, è recomendada por vā rios pesquisadores.

Segundo VILARDEBO et alii (1973), a captura de adultos com armadilhas não representa a população real do in seto, isto porque a praga é muito sujeita a fatôres climāticos, recomendando-se para tanto, coeficiente de infestação, baseado nas galerias produzidas pelas larvas.

Contudo, NANNE e KLINK (1975), YARINGAÑO e Van Der MEER (1975) relataram que o uso de iscas armadilhas ẽ um método satisfatōrio de contrôle da broca, através da co leta manual.

Para SARAIVA (1964) a atratividade das iscas déve-se à seiva, principalmente a do rizoma, que deve conter uma substância ou substâncias, possivelmente um hidrocarbone 
.11.

to aromático volátil, que não só atrai os adultos, como colo ca em ação o mecanismo de oviposição e que essa substância deve ser abundante nas plantas de idade intermediāria.

HORD e FLIPPIN (1956), em pesquisas desenvolvidas em Honduras, MARTINEZ (1971) no Brasil, VARINGANO e Van Der MEER (1975), no Perū, verificaram que iscas de rizomas são mais atrativas que as de pseudocaules.

MARTINEZ (1971) estudando a seleção dos tipos de iscas observou que pseudocaules de plantas que jā produzi ram são mais atrativas que pseudocaules de plantas jovens.

\section{Quanto ao tipo de isca, SIMMONDS e SIMMONDS} (1953), em Trinidad, usaram pedaços de pseudocaules com 45 cm de comprimento, fendidos longitudinalmente, na captura da broca, em Honduras; ROBERTS (1955) mostrou que armadilhas construídas de discos de pseudocaules com $15 \mathrm{~cm}$ de comprimento obtidas pelo corte de plantas colhidas ao nível do solo e colocada sobre a superfície do rizoma é uma eficiente isca e no Brasil, MOREIRA (1984), modificando as iscas de discos de pseudocaules de ROBERTS (1955), conseguiu bons resultados. 


\subsection{Controle}

2.5.1. Controle biológico

0 emprego de fungos entomopatogênicos para controle de pragas da agricultura não é fato recente. Mas, alguns obstäculos, na maioria, de natureza ambiental, têm di ficultado a adoção desse mëtodo, porēm esforços têm sido dirigidos para a utilização de alguns microorganismos patogêni cos no controle biológico da praga.

os fungos entomopatogênicos Beauveria bassiana (Bals) Vuill, Metarrhizium anisopliae (Metsch.) Sorok, Nomuraea rileyi Farlow, Verticilliumlecanii (zimm. ) formam o agrupamento de fungos entomógenos mais frequentes em pesquisas que visam seu emprego como controladores biológicos de pragas.

DEBACH (1969), registrou 175 espëcies de inse tos suscetíveis ao fungo muscardino branco Beauveria bassiana.

Pesquisas conduzidas por Yu-chen (1964), citä do por DELATTRE e JEAN-BART (1978) mostraram que as larvas da broca são mais sensíveis que os adultos à ação do fungo, quando aplicado em suspensão de esporos diretamente sobre os pseudocaul.es. 
DELATTRE e JEAN-BART (1978) constataram a ef ciência da $B$. bassiana como agente patogênico de controle da broca.

No Brasil, VEIGA et alii (1981) acusaram a ocorrencia do fungo causando epizootias sobre a broca da bananeira.

2.5.2. Controle quĩmico

Um dos fatores mais importantes na tomada de decisão do controle de pragas é o conhecimento do seu nível de controle, como colocar em execução e qual a forma mais econômica.

Segundo BULLOCK e EVERS (1962), no Equador, as medidas de controle são aplicadas quando a média de insetos por isca for igual ou superior a um, enquanto que essas medi das tórnam-se desnecessärias, nesse nivel, para as condições do Caribe e América do Sul cujos bananais suportam 5 insetos por isca enquanto na América Central tolera-se de 15 a 20 adultos por isco (PULLEN, 1973).

Em São Paulo, MOREIRA(91979a e 1984) recomenda tomada de medida de controle quando forem encontrados mais de dois adultos por isca. 
No tocante aos mëtodos de controle, esses vão desde as medidas preconizadas por FONSECA (1936), como sejam - arranquio de plantas infestadas, o uso de iscas para atração de adultos, uso de mudas sadias e manejo do bananal, até o uso de produtos químicos empregados nos tratamento de mudas, touceiras e iscas.

o controle da broca nas mudas foi feito, durante muito tempo por meio de afogamento das mesmas. As mudas eram colocadas dentro de um tanque com āgua, ficando totalmente submersas, durante um periodo de 10 a 15 dias. Os resultados eram satisfatōrios, mas muitas mudas se perdiam por fermentação. Com o aparecimento dos inseticidas clorados passou-se a banhar ou polvilhar as mudas antes do seu plantio (MOREIRA, 1984).

SILVA e ABREU (1969), na Bahia, aconselharam - tratamento das mudas e das covas de plantio com produtos à base de aldrin.

Na Costa Rica, BATCHELDER (1954) observou a eficiência do dieldrin durante 40 semanas em plantações de abacā e MATTOS e SIMÃO (1967), em São Paulo, verificaram que bananais tratados com aldrin na cova por ocasião do plantio, não. apresentaram infestação por dois anos.

ZEM e ALVES (1979b) recomendam o uso de carbo furan e diazinon no combate às infestações da broca, em mu- 
das de Nanicão.

0 uso contínuo de clorados por värios anos tornou a'broca resistente a estes produtos em värios estados brasileiros, à semelhança do que ocorre em outros países.

Pesquisas desenvolvidas no Brasil por MELLO e MELLO (1975) mostraram a resistência da broca ao aldrin, ten do esta resistência se revelado em alto nível e cruzada com outros inseticidas clorados, fato tambëm registrado por SOT $\underline{0}$ MAYOR (1972), SHANAHAN e GODDYER (1974) e WRIGHT (1977) para os ciclodienos, principalmente BHC e dieldrin.

No tratamento da touceira, MOREIRA (1971), no Brasil e LICERAS et alii (1973), no Perü, recomendaram apli cações com fensulfothion $5 \%$ G ì razão de 50 a 60 g por planta, enquanto GAUD et alii (1975) verificaram a eficiència do carbofuran 10 G e Dasanit $1.5 \mathrm{G}$ nas dosagens de 10 e $14 \mathrm{~g}$ do ingrediente ativo por planta, respectivamente.

Trabalhos conduzidos por MELLO et alii (1980), em laboratório com adultos de C. sordidus, mostraram que a broca apresenta grande sensibilidade ao aldicarb, mephosfolan, parathion e carbofuran e nenhuma sensibilidade ao clorfenvinfós.

SAMPAIO et alii (1982) indicaram o uso de mephosfolan, 5 G aldicarb 10 G e carbofuran 5 G à razão de 50 , 
.16 .

35 e 50 g por touceira, a intervalos de 90 dias, enquanto ZEM et alii (1981) recomendam aplicações de carbofuran 5 G e fensulfothion $5 \mathrm{G}$ na dosagem de $4 \mathrm{~g}$ por planta para o contro le da broca.

o controle da broca tambèm é feito aplicando- se diretamente o produto na isca.

SOTOMAYOR (1972) mostrou a eficiência do propoxur $1 \%$ e trichlorphon $5 \%$, quando aplicados em iscas semici lindricas e YARINGANO e Van Der MEER (1975) encontraram uma redução de $50 \%$ na população da broca em 4 meses, quando do uso de iscas tratadas com $0,25 \mathrm{~g}$ de carbofuran e $0,2 \mathrm{~g}$ de phenamiphos.

'No Brasil, MOREIRA (1979b) recomendou o trata mento de iscas com fensulfothion $5 \%$, enquanto MELlo et ali $i$ (1979) verificaram que iscas tratadas com carbofuran 5 G e 75 PM e mephosfolan 5 G e 25 E apresentaram-se eficientes por 30 dias.

\subsubsection{Quimioesterilizantes}

o uso de quimioesterilizantes para insetos e outros artrópodos tem sido objeto de estudo de vários pesqui sadores. 
Estes produtos são empregados para interromper a atividade reprodutora, impedindo a formação de ovos e esperma ou danificando o material genético.

TAFT e HOPKINS (1975), estudando os efeitos biolögicos do diflubenzuron no bicudo Anthonomus grandis (Bo heman), demonstraram que este produtor reduziu significativa mente a população da praga.

A ação esterilizante deste produto tem sido constatada para värios curculionídeos: "besouro da raiz dos citros - Diaprepes abreviatus (SCHROEDER et alii, 1976); besouro da ameixa - Conotrachelus nenuphar (CALKINS et alii, 1977) e besouro de "whitefringed" - Graphognathus peregrinus e G. leucoma (OTTENS e TODD, 1979).

De acordo com MOORE et alii (1978), o fator esterilizante do macho pode ser transferido para a fêmea, atravēs de aplicações töpicas.

Pesquisas de CHIN CHANG (1979), em laboratörio, evidenciaram a potencialidade do diflubenzuron, penfluron e SIR 8514 em aplicações töpicas em moscas domésticas, registrando que o penfluron e SIR 8514 foram duas vezes mais potentes que o diflubenzuron.

MILLER et alii (1981), trabalhando com Haematobia irritans (L.), Stomoxys calcitrans (L.), Musca autumna 
lis De Geer e M. domestica L., verificaram que administrando previamente MK 933 ao gado, este produto provocou inibição do desenvolvimento de larvas existentes no esterno dos animais tratados.

Segundo LOFGREN e WILLIAMS (1982), o avermectin $B_{1 a}$ produto derivado de actinomiceto do solo - Streptomy ces avermitilis, provocou inibição da reprodução em rainhas de formigas lavapé Solenopsis invicta Buren, estando estes dados em concordância com aqueles observados por GLANCEY et alii (1982) onde o avermectin B $B_{\text {a }}$ provocou danos irreversíveis nas células ovarianas, caracterizados pelas hipertrofia do ovārio. 


\title{
3. Material e Métodos
}

\author{
Todos os experimentos deste trabalho foram \\ conduzidos em laboratório e campo do Departamento de Entomo \\ logia da Escola Superior de Agricultura "Luiz de Queiroz" da \\ Universidade de São Paulo, em Piracicaba e no Departamento \\ de Fitotecnia do Centro de Ciências Agrärias da Universidade \\ Federal da Paraiba em Areia.
}

3.1. Comportamento da broca da bananeira Cosmopolites sor didus (Germar, 1824)

3.1.1. Preferéncia pelo local e idade da planta

o comportamento dos insetos em presença de bulbos e pseudocaules da bananeira foi estudado em laborató- 
rio.

os insetos foram colocados em depósitos plásticos transparentes, contendo aberturas laterais onde foram adaptadas mangueiras plásticas de $1 / 2$ polegada, formando canais que se ligavam a copinhos plásticos. Estes copinhos, tendo sua boca vedada pelo tecido de nylon, preso com elásti co, continham em sua base, fina camada de areia umedecida e em cada um deles uma porção do material vegetal a analisar (Figura 1).

Os tratamentos constaram de:

1. Pseudocaule de plantas jovens

2. Rizoma de plantas jovens

3. Pseudocaule de plantas com cacho

4. Rizoma de plantas com cacho

5. Pseudocaule de plantas que produziram cacho

6. Rizoma de plantas que produziram cacho

Neste ensaio chamou-sede planta jovem àquela com 1,20 a $1,30 \mathrm{~m}$ de altura, antes da emissão de inflorescência.

0 ensaio constou portanto de 6 tratamentos e 4 repetições sendo que cada repetição recebeu 60 insetos, de ambos os sexos, com livre chance de escolha. 


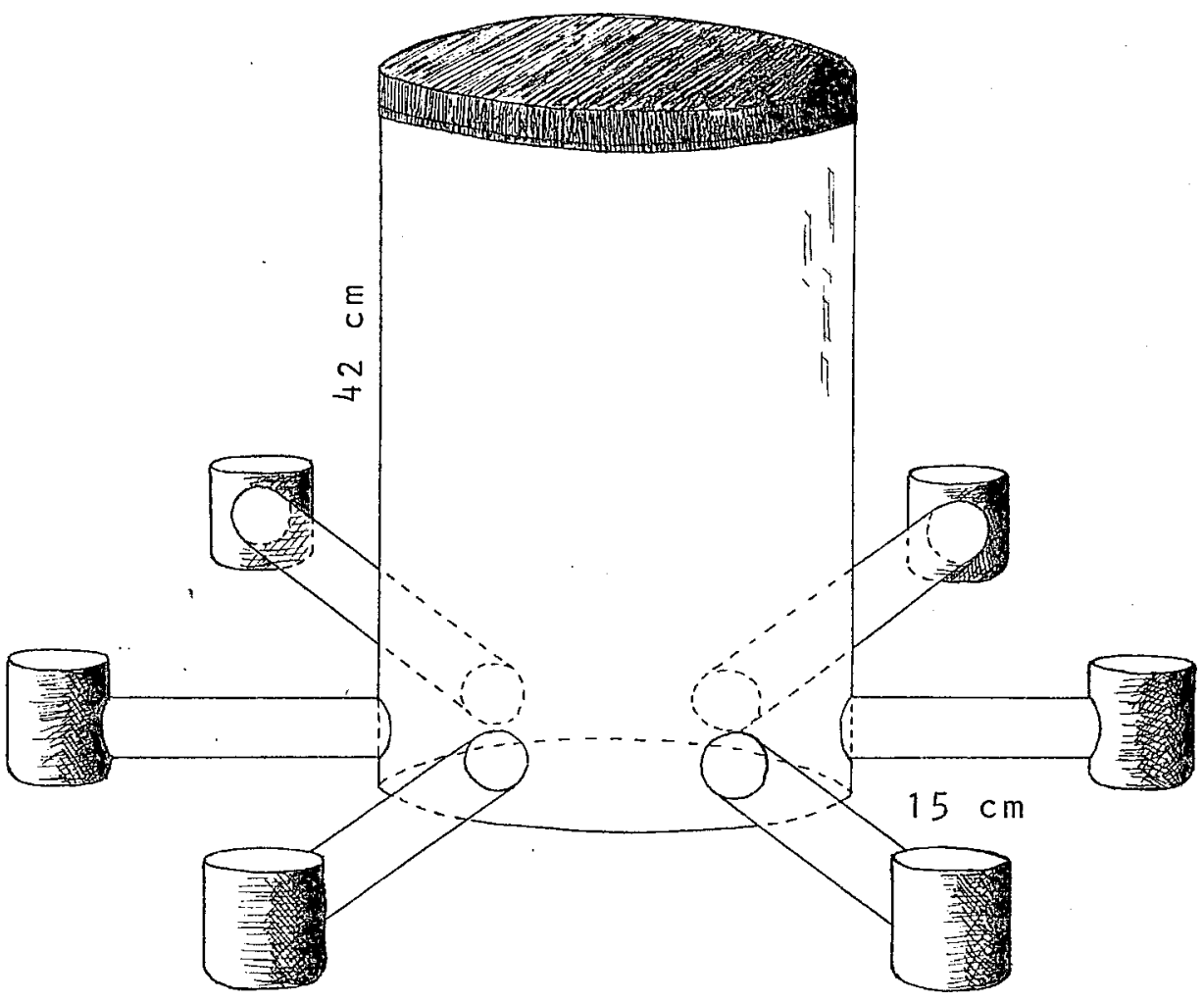

FIGURA 1. Desenho esquemātico do dispositivo usado no estudo do comportamento da broca da bananeira. 
Para avaliar a preferência pelo local e região da planta, foram feitas observações relativas ao nūmero de insetjos sobre cada alimento, 24 e 48 horas após a instala ção do ensaio.

o delineamento estatístico adotado foi inteiramente casualizado em arranjo fatorial $6 \times 2$ e as médias comparadas pelo teste de Tukey.

3.1.2. Teste de substāncias no aumento da atrativida de das iscas

Este ensaio foi realizado em laboratörio, com caixas plásticas contendo no seu interior uma camada de areia umedecida.

Os tratamentos constaram de iscas de pseudocaules tratadas com $5 \mathrm{ml}$ dos seguintes produtos: álcool $5^{\circ} \mathrm{e}$ $75^{\circ} \mathrm{GL}$ e melaço a 15,20 e $25 \%$.

As iscas foram distribuidas inteiramente ao acaso dentro das caixas plästicas, onde no centro foram libe rados 10 insetos por repetição.

Decorridos 24,48 e 72 horas, foi anotado o nümero se insetos atraídos pelas iscas, e os dados obtidos analisados em arranjo fatorial $6 \times 3$, e as médias comparadas 
pelo teste de Tukey.

3.1.3. Dispersão

Para o estudo de movimentação da população de C. sordidus utiliżou-se o método de marcação e recaptura baseada na de DELATTRE (1980), com modificações introduzidas em relação à unidade experimental. Utilizaram iscas em discos em substituição à área subdividida dentro da plantação.

Como unidade experimental usaram-se iscas de pseudocaules obtidas do primeiro metro da planta colhida, a partir do nível do solo.

As iscas, cortadas em discos foram colocadas em contato com o solo e distribuídas no centro da área do ba nanal (Figura 2).

0s insetos marcados, em nümero de 60 , foram liberados na isca central do grupo de iscas e diariamente feitos registros de seu deslocamento dentro do bananal.

No bananal foram espalhadas iscas tipo telha, sendo que os insetos marcados e recapturados foram remarcados e devolvidos a isca central da unidade experimental. 


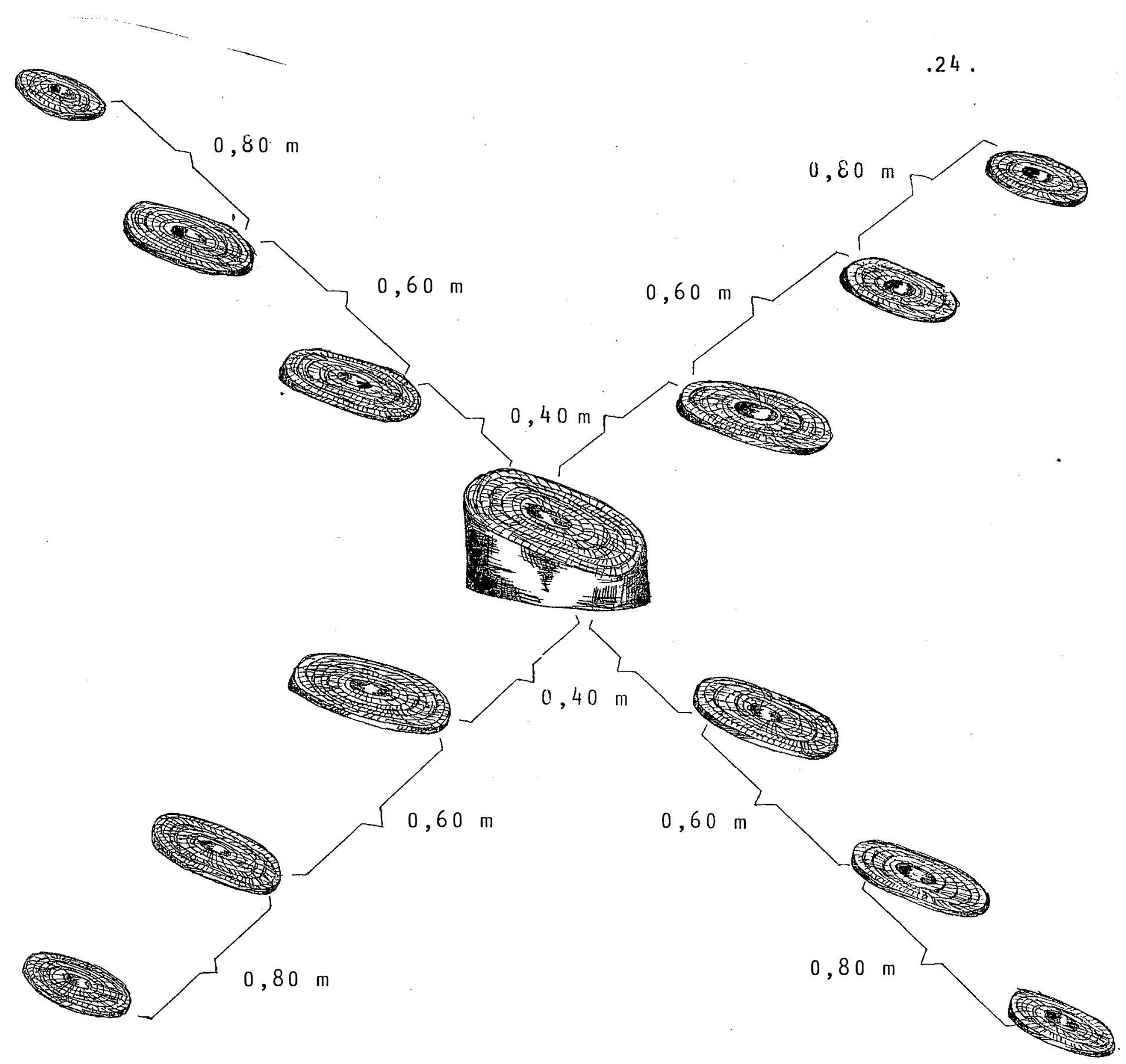

FIgURA 2. Desenho esquemático da unidade experimental usado no estudo de movimentação da população de C. sordi dus. 
3.1.4. Influēncia da temperatura sobre a dispersão

Neste ensaio, prodeceu-se, no que se refere ao dispositivo, de modo idêntico ao ítem 3.1.1., utilizando-se como iscas, pseudocaules de plantas que produziram cacho.

Este dispositivo foi levado a estufa às tempe raturas de $10^{\circ}, 15^{\circ}, 20^{\circ}, 30^{\circ}, 35^{\circ}$ e $40^{\circ} \mathrm{C}$.

os insetos em nümero de 30 por repetição foram colocados no depósito central e a cada hora foi anotado o nümero de indivíduos que se deslocaram atë as iscas nas duas repetições.

\subsection{Aspectos biolögicos}

A biologia de C. sordidus, em laboratōrio foi estudada a partir de adultos procedentes do campo, coletados com o uso de iscas de pseudocaules e mantidos em caixas de criação a temperatura ambiente e alimentados com pseudocaules.

Nesta pesquisa, foram utilizadas garrafas plàsticas de āgua mineral, as quais foram seccionadas à 10 cm da base. Para estes depósitos contendo uma camada de areia umedecida e pedaços de pseudocaule (região do colo) fo 
ram transferidos 100 insetos.

Atravēs de observações diārias foi possível o exame dos ovos depositados tanto na bainha como no rizoma. Estes ovos foram contados, tratados com formaldeído a $5 \%$ e colocados em placas de Petri, forradas com papel de filtro previamente umedecido com àgua destilada.

A proporção que ia ocorrendo a eclosão das. larvas, fazia-se a sua transferéncia para depósitos contendo camada de areia umedecida e pedaços de planta (pseudocaule- rizoma).

Foram observados os seguintes parâmetros biolōgicos: período de incubação e duração, viabilidade das fases larval e pupal.

\subsection{Flutuação populacional}

A presente pesquisa, realizou-se numa ärea de aproximadamente $1.500 \mathrm{~m}^{2}$ da cultivar Prata, junto ao Departamento de Fitotecnia do Centro de Ciências Agrärias da Universidade Federal da Paraíba em Areia, Paraíba.

Para determinar a movimentação anual da broca, foram distribuídas ao acaso iscas de pseudocaules, obtidas do primeiro metro de planta colhida, a partir do nível 
do solo.

As iscas, com $0,50 \mathrm{~m}$ de comprimento, secciona das longitudinalmente, foram colocadas com a face cortada em contato com o solo nas proximidades da touceira previamente limpa.

As contagens dos insetos foram feitas semanal mente com a remoção dos insetos da área e substituição quinzenal da isca.

Para a análise dos dados foram feitas correla ções simples, entre o número de insetos capturados e as médias mensais dos fatores climáticos.

3.4. Patogenicidade do fungo Beauveria bassiana (Bals.) Vuill

3.4.1. Patōgeno

A cepa do fungo Beauveria bassiana (Bals.) Vuill foi procedente da Estação Experimental de Itapirema-PE da Empresa Pernambucana de Pesquisa Agropecuária tendo sido coletado de brocas com infecção natural. 
3.4.1.1. Meio de cultura

0 substrato empregado na multiplicação do fun go foi árroz autoclavado em erlenmeyer. Numa câmara assépti ca foi feita a repicagem do material.

3.4.1.2. Quantificação e viabilidade do inōcu 10

Tomou-se um erlenmeyer para onde foram transferidas porções do meio de cultura mais o fungo esporulado. Em seguida adicionaram-se $200 \mathrm{ml}$ de ägua destilada, agitou- se bem de modo a ter uma susfensão de esporos.

Para se determinar a concentração de esporos, tomou-se uma amostra dessa suspensão transferindo-a para uma câmara de Neubauer e posteriormente efetuando-se as leituras uti lizando-se um microscópio.

Uma vez conhecida a concentração de esporos, a determinação de sua viabilidade para fins de potencial de inóculo foi efetuada espalhando-se uma gota da suspensão em BDA numa placa de Petri; atravēs de uma pipeta de l ml, divi dida em $0,1 \mathrm{ml}$. Em seguida, espalhou-se a suspensão na superfície do meio com uma alça de Drigalky. Apōs 24 horas, em temperatura ambiente, procedeu-se a avaliação dos esporos viàveis. 


\subsubsection{Inseto-teste}

Para se testar a patogenicidade do fungo em adultos d'a broca da bananeira $C$. sordidus, tais insetos foram previamente coletados e mantidos em laboratório por 15 dias a fim de se certificar da não ocorrência de uma possível infecção natural. Constatada, a não infecção destes insetos foi feita uma suspensão de inóculo na base de $2,0 \quad x$ $10^{9}$ esporos viāveis por ml.

0 ensaio constou de 4 tratamentos e 5 repetições, sendo os tratamentos representados:

1. Imersão de adultos na suspensão

2. Pulverização com suspensão de inōculo sobre pseudocaule

3. Aplicação do solo (areia)

4. Testemunha

Para a execução desta etapa foram usadas placas de Petri forradas com areia esterilizada sobre a qual fo ram distribuídas pedaços de pseudocaule. As placas, proteg das com gaiolas, receberam 10 insetos por repetição.

Apōs a inoculação, os insetos foram mantidos em temperatura ambiente e anotada a porcentagem de mortalida de. 


\title{
3.5. Controle químico
}

\begin{abstract}
Foram realizados ensaios de laboratōrio, com caixas plásticas contendo no seu interior uma camada de areia umedecida e protegidas por plástico transparente.
\end{abstract}

Cada ensaio constou de 6 tratamentos com 4 re petições. Os tratamentos adotados com discriminação das denominações, formulações e dosagens estão reunidos na Tabela 17.

\subsubsection{Estudo comparativo de inseticidas clorado e} carbamatos na atratividade de iscas

Os tratamentos constaram de iscas de pseudocaules tratadas com aldrin 5 PS, aldicarb 10 G, bendiocarb 3 G, carbofuran 5 G, carbaril 80 PM à razão de $0,288 \mathrm{~g}, 0,072$ $\mathrm{g}, 0,216 \mathrm{~g}, 0,144 \mathrm{~g}$ e $0,018 \mathrm{~g}$ respectivamente, por ärea expe rimental.

As iscas foram distribuídas inteiramente ao acaso, dentro das caixas plāsticas, onde no centro foram liberados 10 insetos por repetição.

Para se avaliar o efeito dos produtos testados foram feitas contagens após 24 e 48 horas da aplicação e anotados o nümero de insetos vivos e mortos. 
Para o cälculo da eficiència dos inseticidas utilizou-se a förmula de Abbott assim indicada:

$$
\begin{aligned}
& \%=\frac{T-t}{T} \times 100 \\
& T=\text { nümero de insetos vivos na testemunha } \\
& t=\text { nümero de insetos vivos no tratamento }
\end{aligned}
$$

0 delineamento estatístico adotado, foi o de inteiramente ao acaso e os dados de percentagem de mortalida de foram transformados em arc sen $\sqrt{P / 100}$, onde $P$ significa percentagem de mortalidade. Fara os valores de $\mathrm{P}$ iguais a zero, substituiu-se por $100 / 4 \mathrm{n}$ e os iguais a 100 por 100 $(1+1 / 4 n)$, onde n significa o nivel de infestação (BARTLET:T, 1947).

Estes resultados foram analisados estatistica mente e as mëdias de tratamentos comparadas pelo teste de Tu key, ao nível de $5 \%$ de probabilidade.

3.5.2. Uso de quimioesterilizante

Neste ensaio, os insetos em estudo foram agru pados em 1 (um) casal e 20 (vinte) insetos por tratamento. 
caules tratadas com os seguintes produtos nas dosagens do in grediente ativo por diflubenzuron $25 \%$ PM, methoprene $5 \%$ CE, oxicloreto de cobre $50 \%$ PS, trifluron $6,5 \%$ CE e avermectin $1,8 \% \mathrm{~s}$, atravēs da imersão das iscas por 15 minutos.

Os insetos de ambos os sexos foram confinados em depösitos onde receberam os alimentos tratados.

Para se avaliar o efeito esterilizante dos. produtos testados foram feitas contagens apös 15,30 e 45 dias da aplicação e anotados o nümero de ovos postos e o número de larvas nascidas.

Em estudos anatômicos do aparelho reprodutor, os insetos adultos de C. sordidus, depois de submetidos aos tratamentos e mortos, após a remoção das asas, foram cuidado samente alfinetados pelo dorso num bloco de parafina contido em placa de Petri, e eviscerados em meio de solução físiológica de Krijgsman. Nesta ocasião, com um microscōpio estereoscōpio marca olympus foram feitas as observações sobre a ocorrência de anormalidades. 


\title{
4. Resultados e Discussão
}

\author{
4.1. Comportamento da broca da bananeira C. sordidus em \\ presença de pseudocaule e rizoma
}

\subsubsection{Atratividade}

Os dados referentes ao preferendo pseudocaule e rizoma encontrama.-se na Tabela 1 , nos quais o número de adultos de $C$. sordidus atraidos, acham-se transformados em $\sqrt{x+0,5}$. Os contrastes entre as mëdias avaliados pelo tes te de Tukey e a análise de variância, na qual f foi significativo ao nivel de $1 \%$ de probabilidade são apresentados nas Tabelas 2 e 3 .

$$
\text { observando-se estes resultados, verifica-se }
$$
que não houve diferença significativa "entre" o material vegetal e sim "dentro" do material a analisar. No primeiro ca 


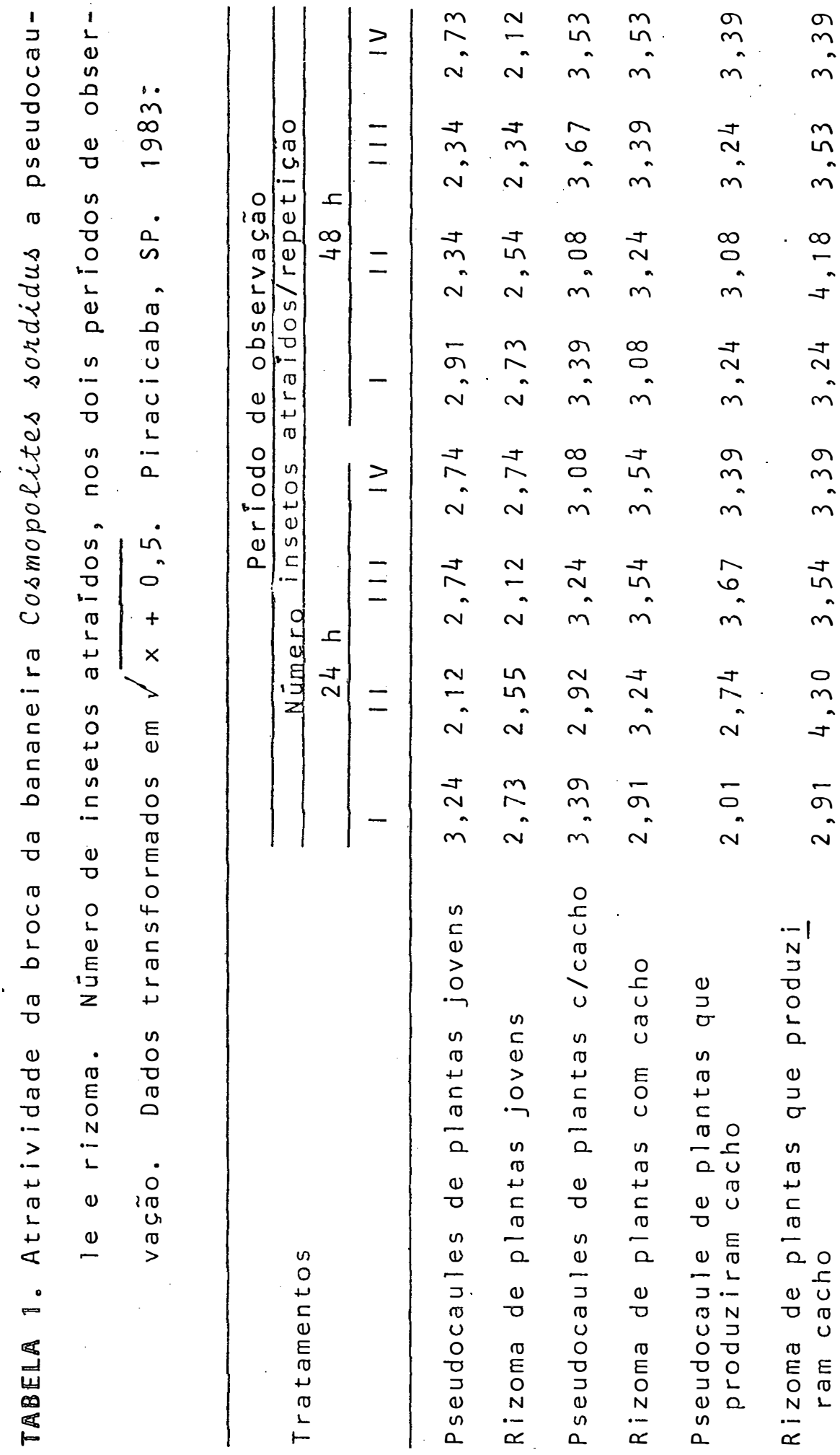




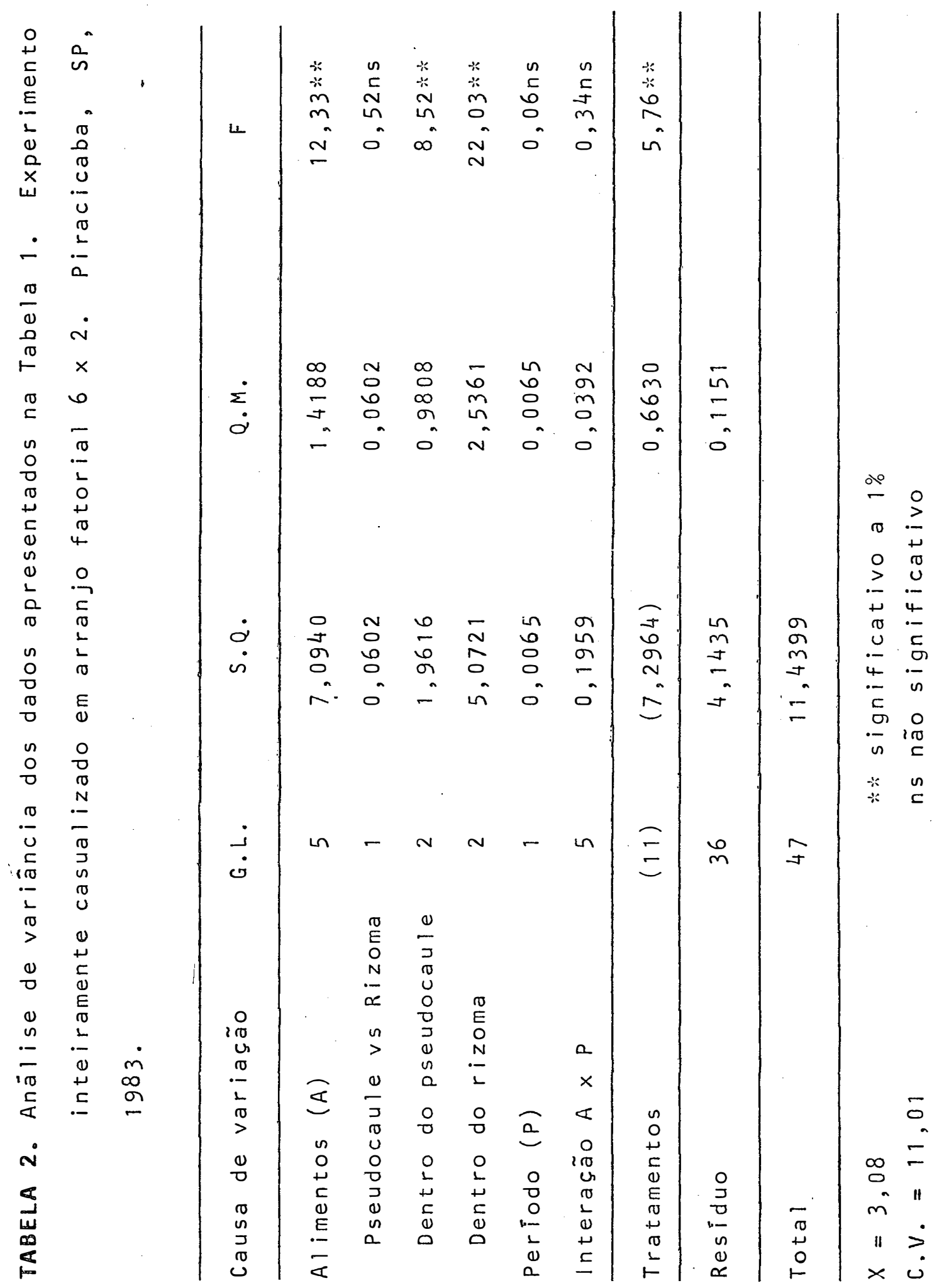


TABELA 3. Nümero mëdio de adultos de C. sordidus atraídos, nos diferentes tratamentos, em condições de labora - tório. Piracicaba, SP, 1983.

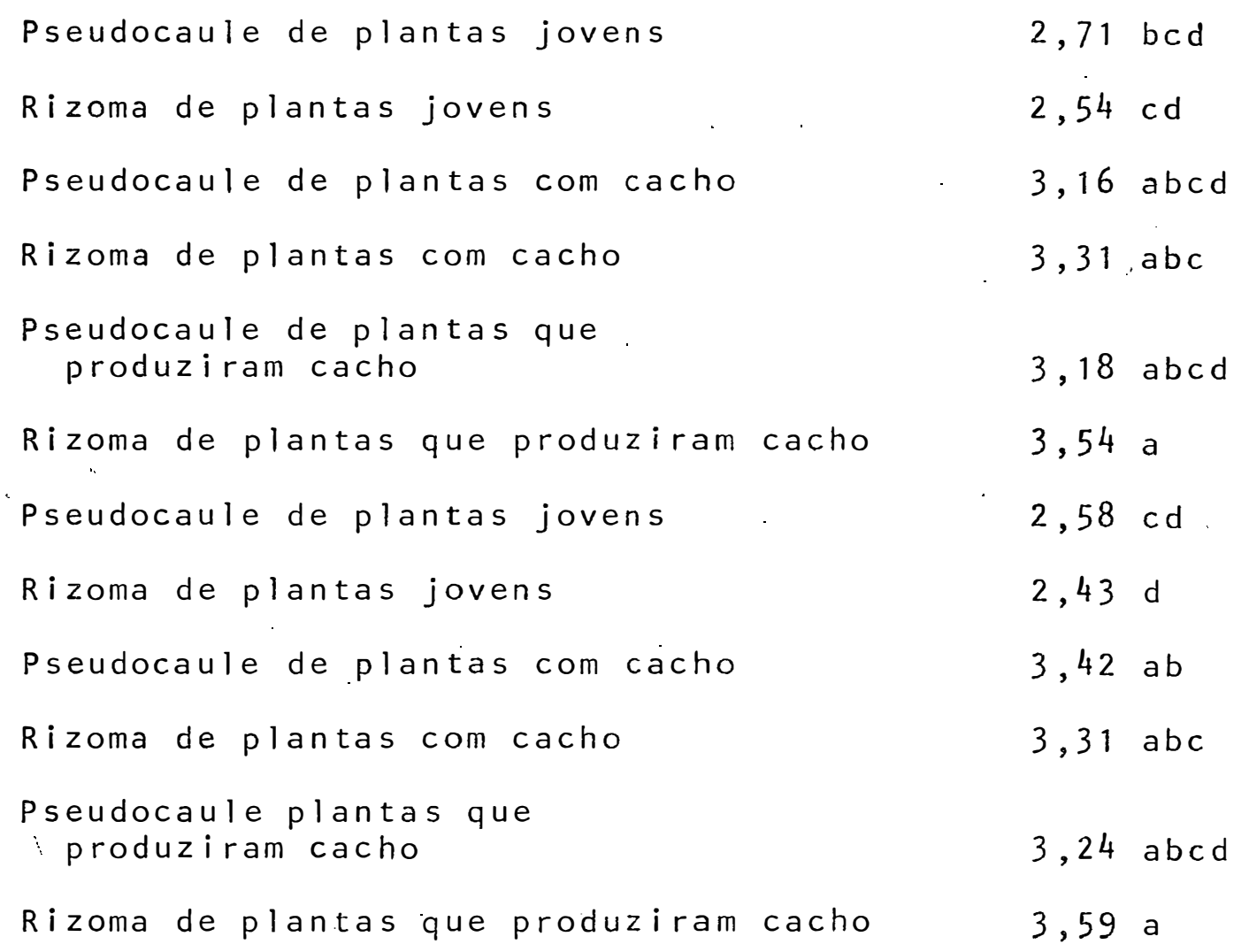

* Médias seguidas da mesma letra, não diferem significativamente ao nivel de $5 \%$ de probabilidade.

D.M.S. (Tukey 5\%) $=0,83$ 
5o, isto quer dizer que, iscas feitas de pseudocaule e rizoma não diferem quanto a atratividade e no segundo caso, pare ce que a, atratividade estā em função da idade da planta; assim, plantas mais jovens são menos atrativas que plantas de idade intermediāria, que são menos atrativas que plantas que produziram cachos. Estes resultados, assemelham-se àqueles obtidos por MARTINEZ (1971).

Com relação a preferência para oviposição, fo ram encontrados alguns ovos sobre o rizoma; isto sugere a ação do acaso ou à tendência para oviposição em plantas de idade intermediäria. Contudo, estudos deverão ser feitos a fim de que se possa confirmar estas hipóteses.

Na Tabela 4, é apresentado o resumo do compor tamento de $C$. sordidus em presença de pseudocaule e rizoma.

4.1.2. Substâncias para aumento da atratividade das iscas

Nas Tabelas 5,6 e 7 são apresentados os resultados referentes a este ensaio, avaliados pelos testes de Tukey, com os dados transformados em $\sqrt{x+0,5}$ e a anälise de variância na qual $F$ foi significativo ao nível de $1 \%$ de probabilidade, obtidos com o nümero de adultos da broca atraídos nas iscas de pseudocaules tratadas. 


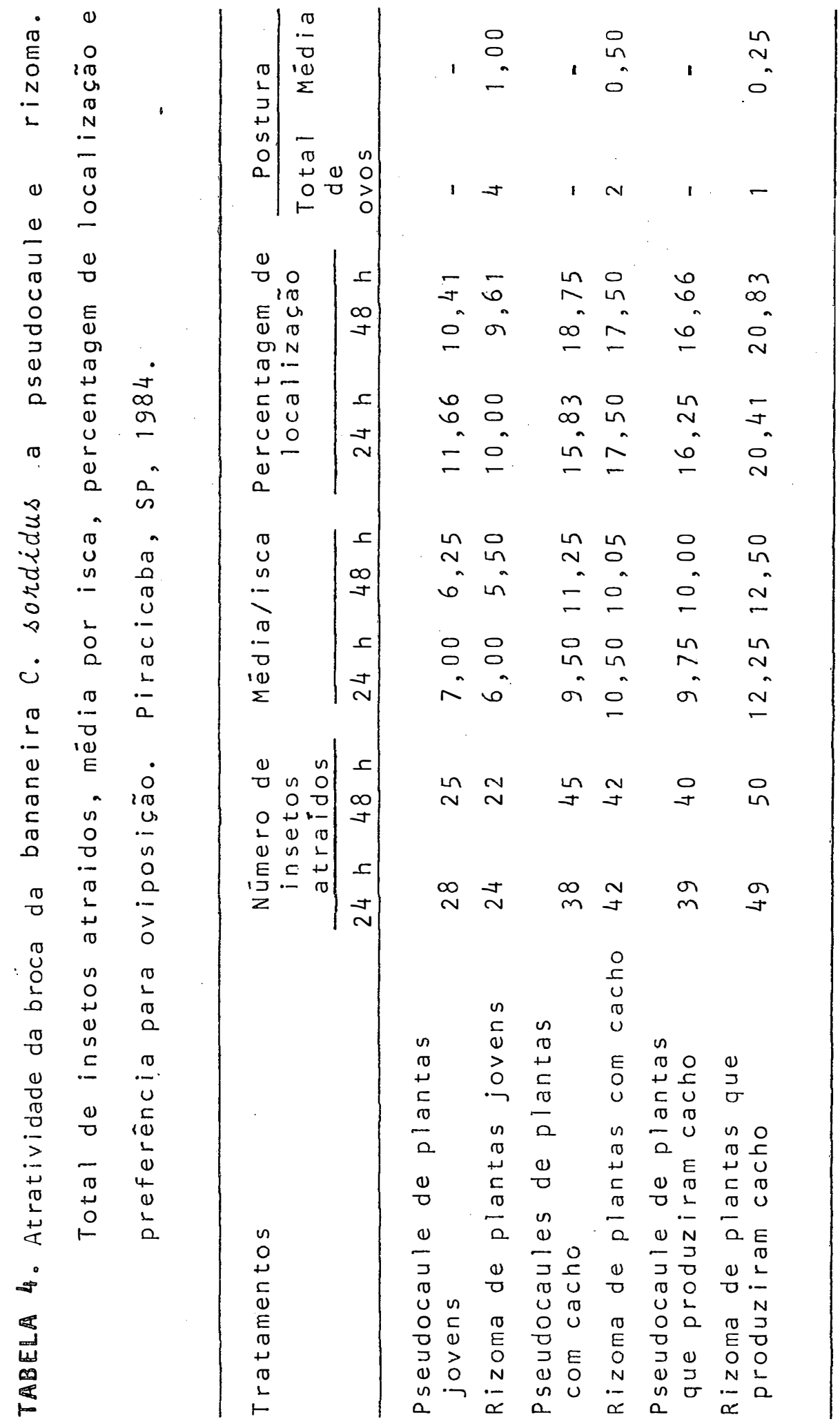


TABELA 5. Número de adultos de C. sordidus, coletados em iscas de pseudocaules tratadas com diferentes substâncias. Dados transformados em $\sqrt{x+0,5}$. Piraci caba, SP. 1983.

\begin{tabular}{|c|c|c|c|c|c|c|c|}
\hline \multirow{2}{*}{\multicolumn{2}{|c|}{$\begin{array}{l}\text { Período de } \\
\text { Observação* }\end{array}$}} & \multicolumn{6}{|c|}{ Tratamentos } \\
\hline & & $\bar{A} \mid c 001$ & $\bar{A} \mid c 00 l$ & Mel aço & Melaço & Melaço & Teste \\
\hline \multicolumn{8}{|c|}{$24 \mathrm{~h}$} \\
\hline & 1 & 1,22 & 0,71 & 1,50 & 1,58 & 0,71 & 2,12 \\
\hline & 11 & 0,71 & 1,87 & 0,71 & 1,22 & 1,87 & 1,87 \\
\hline & 111 & 1,58 & 0,71 & 1,87 & 0,71 & 1,22 & 1,87 \\
\hline & IV & 0,71 & 1,58 & 0,71 & 0,71 & 0,71 & 2,91 \\
\hline & V & 0,71 & 1,22 & 0,71 & 0,71 & 1,22 & 2,91 \\
\hline & V.I & 0,71 & 0,71 & 2,34 & 0,71 & 0,71 & 2,34 \\
\hline & V! I & $0,7,1$ & 0,71 & 1,58 & 0,71 & 1,58 & 2,34 \\
\hline
\end{tabular}

$48 \mathrm{~h}$

$\begin{array}{lllllll}\text { I } & 1,58 & 0,71 & 1,22 & 2,34 & 0,71 & 1,22 \\ \text { II } & 0,71 & 1,58 & 0,71 & 1,87 & 1,58 & 1,58 \\ \text { III } & 1,58 & 0,71 & 1,87 & 0,71 & 1,58 & 1,87 \\ \text { IV } & 1,22 & 2,12 & 0,71 & 0,71 & 0,71 & 2,34 \\ \text { V } & 0,71 & 1,87 & 0,71 & 0,71 & 1,58 & 2,12 \\ \text { VI } & 1,87 & 0,71 & 2,12 & 0,71 & 0,71 & 1,58 \\ \text { VII } & 0,71 & 0,71 & 1,87 & 1,58 & 1,58 & 1,87\end{array}$

$72 \mathrm{~h}$

$\begin{array}{lllllll}\text { I } & 1,87 & 0,71 & 0,71 & 1,22 & 0,71 & 1,87 \\ \text { II } & 0,71 & 2,34 & 1,22 & 1,58 & 0,71 & 1,22 \\ \text { III } & 1,22 & 0,71 & 1,22 & 0,71 & 1,22 & 2,34 \\ \text { IV } & 0,71 & 2,34 & 0,71 & 0,71 & 0,71 & 2,34 \\ \text { V } & 0,71 & 2,12 & 0,71 & 0,71 & 1,58 & 2,12 \\ \text { VI } & 1,22 & 1,58 & 1,58 & 0,71 & 0,71 & 1,58 \\ \text { VII } & 0,71 & 0,71 & 1,58 & 1,87 & 1,22 & 2,12\end{array}$

* Número de insetos atraídos/repetição. 
.40 .

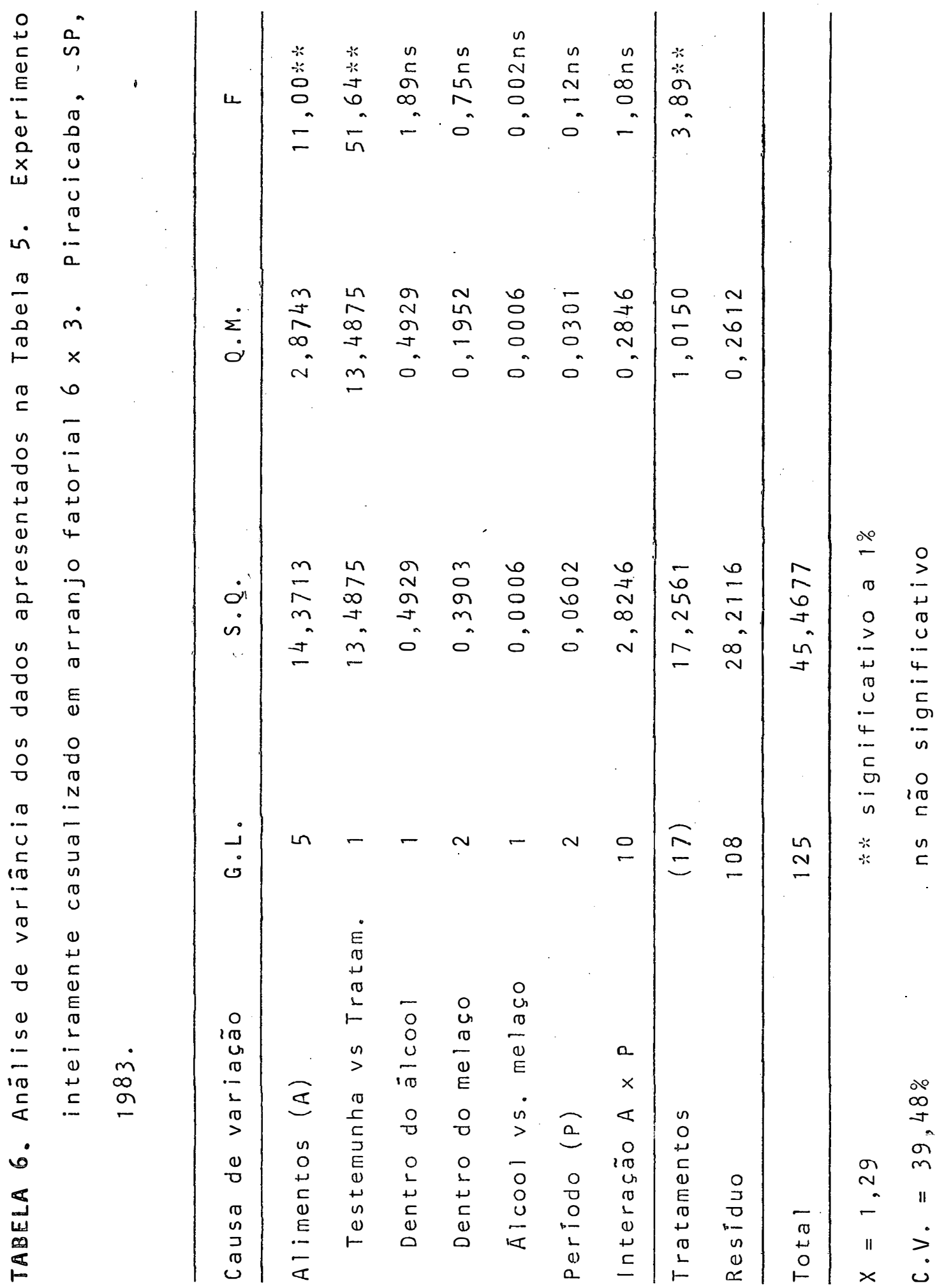


TABELA 7. Número de adultos de $C$. sordidus atraidos, nos diferentes tratamentos, em condiçōes de laboratōrio. - Piracicaba, SP. 1983.

Tratamentos

\section{Médias dos tratamentos*}

Testemunha vs. trat.

Testemunha

Demais tratamentos

Dentro do älcool

Alcool 50

Alcool 70

Dentro do' melaço

Melaço 15

Melaço 20

Melaço 25

$$
2,03 \text { a }
$$

$1,15 \mathrm{~b}$

1,04 a

1,26 a

1,25 a

1,07 a

$1,11, a$

* Mëdias seguidas da mesma letra, não diferem significativamente ao nivel de $5 \%$ de probabilidade.

D.M.S. (Tukey 5\%) $=0,95$ 
Em relação à influência de substâncias no aumento da atratividade das iscas, constatou-se que estatisticamente os tratamentos não diferiram entre si, mas apenas da testemunha, estando em acordo com os estudos de NOGUEIRA (1975) para C. sordidus em campo. Entretanto, hä discordância com as observações realizadas por CUILLE (1950), em condições de laboratōrio, com olfatômetro, que proporcionou alta percentagem de respostas positivas dessa praga em relação a älcool etílico mais extrato etéreo de rizoma.

\subsubsection{Dispersão}

Os resultados do ensaio, com.o total de adultos de C. sordidus marcados e recapturados, são apresentados nas Tabelas 8 e 9 .

No ensaio, observando-se os dados, constatou- se que no 1: dia após a liberação dos insetos na unidade ex perimental dentro do bananal, do grupo de 60 insetos marcados e liberados, os mais afastados achavam-se a $0,40 \mathrm{~m}$ e $0,60 \mathrm{~m}$; no nono dia depois da liberação apenas um inseto encontrava-se afastado $0,40 \mathrm{~m}$ dentro da unidade experimental e 5 (cinco) insetos achavam-se distanciados da unidade 2,15 $\mathrm{m}-3,05 \mathrm{~m}-4,75 \mathrm{~m}$ e $7,10 \mathrm{~m}$. No vigésimo primeiro dia, ape nas 1 (um) inseto permanecia afastado $0,40 \mathrm{~m}$ enquanto que os demais possivelmente teriam retornado às touceiras de ba- 
.43.

TABELA 8. Nümero total de insetos capturados em iscas de pseudocaule na unidade experimental de campo, du- rante 30 dias de observação. Piracicaba, SP: 1983

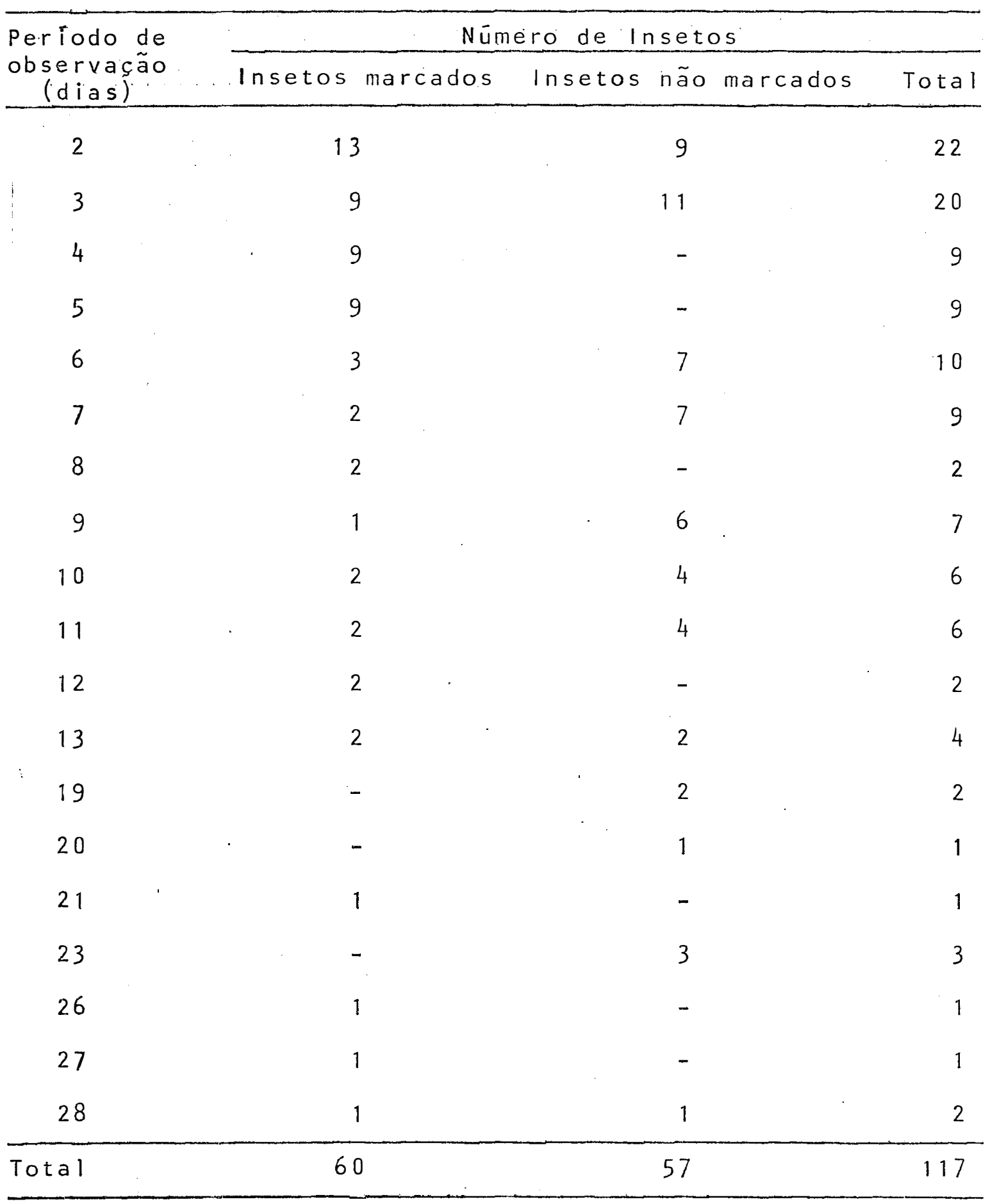


.44.

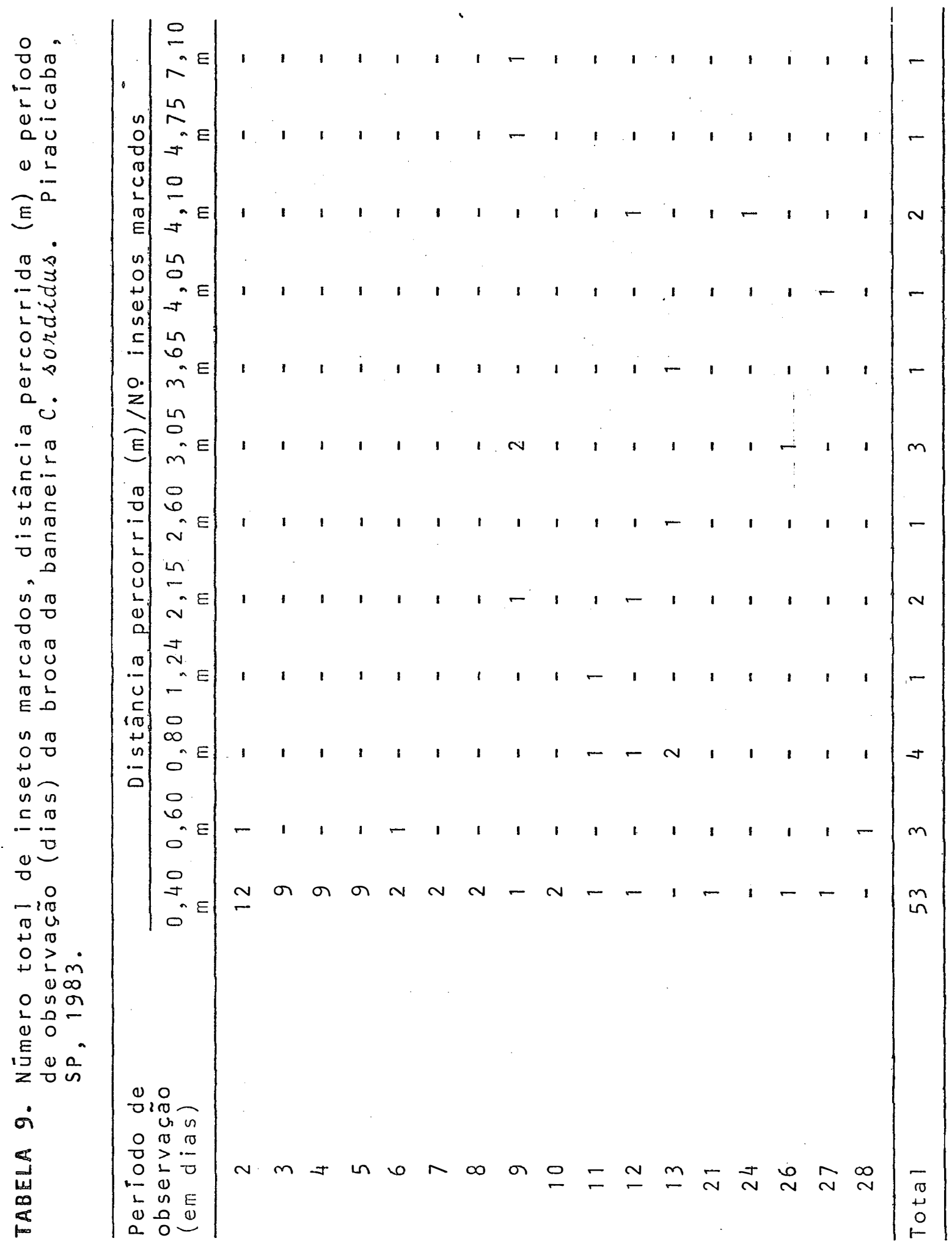


naneira, onde não foi possível mais recapturā-los, isto por- que as touceiras são seu habitat natural e isto lhes proporciona melfores condições de abrigo e alimentação. Estes resultados estão em concordáncia com aqueles obtidos por Walla ce $(1938)$, citado por CUILLE (1950), no que diz respeito ao häbito sedentärio do inseto.

4.1.4. Influência da temperatura na dispersão de $C$. sordidus

Através dos dados registrados na Tabela 10 e Figura 3, relacionando-se as temperaturas com o nümero médio de insetos que se deslocaram no teste, evidenciou-se que a atividade normal da broca da bananeira está.entre as tempera turas 20 e $30^{\circ} \mathrm{C}$. Nos extremos de temperatura, os insetos permaneceram imóveis e agrupados, ocorrendo a mortalidade de todos individuos a $10^{\circ} \mathrm{C}$ e de $66,7 \%$ a $40^{\circ} \mathrm{C}$.

0s resultados desta pesquisa, concordam com os de CUILLE (1950) que encontrou o termopreferendo da broca nessa mesma faixa com temperatura ótima de atividade a $25^{\circ} \mathrm{C}$. 
TABELA 10. Nümero médio de adultos de $C$. sordidus submetidos a diferentes temperaturas, em condições de labora - törio. Piracicaba, SP. 1983.

\begin{tabular}{|c|c|c|c|c|c|c|}
\hline \multirow{2}{*}{$\begin{array}{l}\text { Periodo de } \\
\text { Observação } \\
\text { (horas) }\end{array}$} & \multicolumn{3}{|c|}{ Temperatura/nümero } & \multicolumn{3}{|c|}{ médio de insetos } \\
\hline & $10^{\circ} \mathrm{C}$ & $15^{\circ} \mathrm{C}$ & $20^{\circ} \mathrm{C}$ & $30^{\circ} \mathrm{C}$ & $35^{\circ} \mathrm{C}$ & $40^{\circ} \mathrm{C}$ \\
\hline $1: 00$ & $-*$ & 12 & 13 & 13 & 10 & $10 *$ \\
\hline $2: 00$ & - & 6 & 14 & 14 & 8 & - \\
\hline $3: 00$ & - & 2 & 8 & 19 & 6 & - \\
\hline $4: 00$ & - & 6 & 12 & 11 & 8 & - \\
\hline $\begin{array}{l}\% \text { de respostas } \\
\text { positivas }\end{array}$ & - & 43,33 & 78,33 & 95,00 & 53,00 & - \\
\hline
\end{tabular}

* Insetos mortos

- Não houve deslocamento 


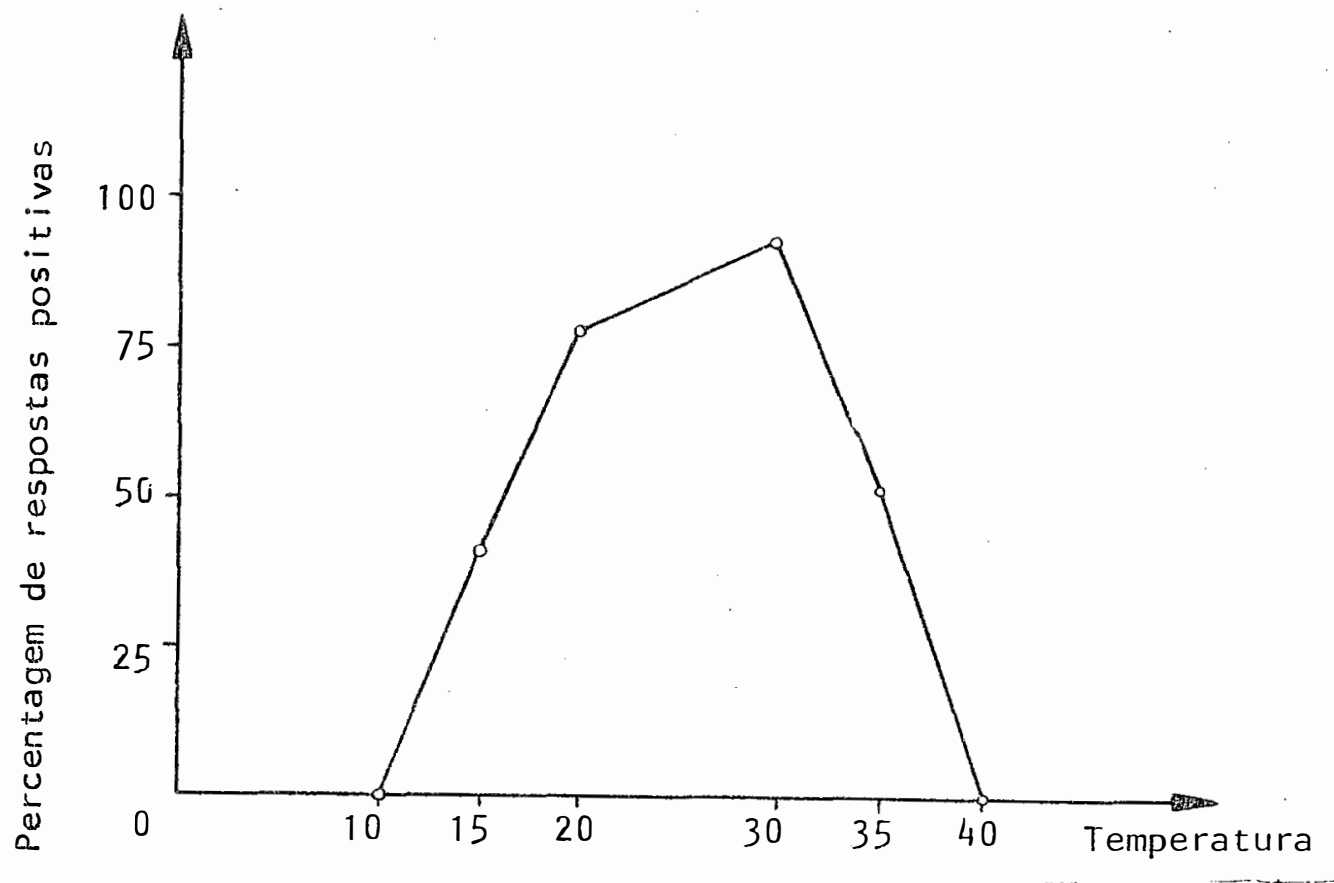

FIGURA 3. Influência da temperatura sobre a dispersão da bro ca da bananeira C. sordidus. Piracicaba, Sf. 1983. 
4.2. Aspectos biológicos

Esta prática, provocou alterações no comportạ mento do "inseto, forçando-o a uma oviposição anormal.

o total de ovos obtidos em laboratório foi de 84 com uma porcentagem de eclosão de 29,76 e o período de ín cubação médio de 6,94 $\pm 0,63$ dias e intervalo de dispersão que variou de 3 e 12 dias. O elevado indice de mortalidade foi possivelmente consequência de condições inadequadas a que foram submetidos os adultos, estimulando-os a uma oviposição prematura com esterilidade dos ovos. O período larval variou entre 25 e 30 dias e em média $27,40 \pm 0,81$ dias, com viabilidade de 25\%. Em virtude do häbito do inseto, não se determinou o nūmero de ínstares larvais e nem estudos detalhados sobre o estāgio pupal, o qual foi em média de 10,33 \pm 0,67 dias, variando de 9 a 11 dias, com viabilidade de $60 \%$.

Os resultados desta pesquisa, diferem daqueles obtidos por FONSECA (1936), ROBERTS (1955), MESQUITA et. alii (1984), possivelmente devido a diferenças nas condiçöes em que foram desenvolvidos esses trabalhos.

os dados referentes ao ciclo biológico encontram-se condensados na Tabela 11. 


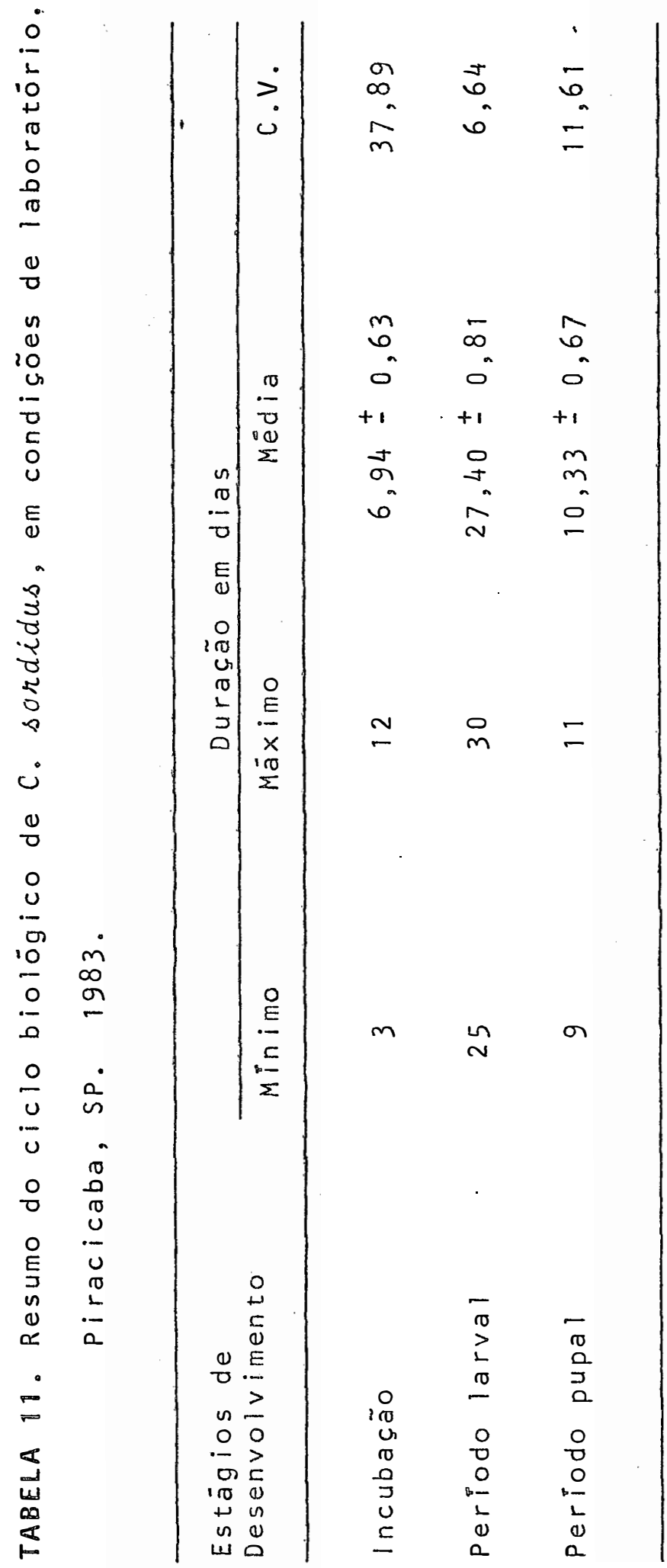




\subsection{Flutuação populacional}

Os dados referentes a flutuação da população

de C. sordidus no município de Areia, PB, encontram-se na Ta bela 12. Nas Tabelas 13 e 14 são apresentados os fatores climáticos e a análise de correlação simples (r).

A flutuação mēdia anual de C. sordidus obtida por meio de isca, mostra que os maiores picos ocorreram em. setembro e dezembro sendo a população possivelmente afetada pelos fatores climáticos durante o período de abril a junho, onde registrou-se as menores populações e as maiores precipi taçöes pluviomëtricas (Figura 4).

As correlações entre os dados de flutuação da praga e os fatores meteorológicos mostraram que houve uma correlação negativa. e significativa ao nível de $1 \%$ de probabilidade entre o nümero de adultos e a precipitação pluviomé trica e ao nível de $5 \%$ de probabilidade para umidade relativa mëdia, confirmando ZEM et alii (1979), VEIGA et alii (1981) e ARLEU. (1982). Por outro lado, verificou-se que nà̃o houve correlação entre o nümero de adultos de $C$. sordidus e a temperatura, resultados que concordam com aqueles obtidos por OLIVEIRA et alii (1976). 
TABELA 12. Nümero mëdio de adultos de $\mathcal{C}$. sondidus, coletados em 15 iscas de pseudocaule do cultivar Prata, du- rante 1984. Areia, PB. 1985.

\begin{tabular}{lc}
\hline Meses & Nümero mëdio de insetos por isca \\
\hline janeiro & 1,33 \\
fevereiro & 1,20 \\
marso & 1,00 \\
abril & 0,80 \\
maio & 0,80 \\
junho & 0,80 \\
julho & 0,86 \\
agosto & 0,93 \\
setembro & 1,53 \\
outubro & 1,33 \\
novembro & 1,44 \\
dezembro & 1,66 \\
\hline Total & 13,70 \\
\hline Mëdia & 1,14 \\
\hline
\end{tabular}


TABELA 13. Mëdias mensais de temperatura $\left({ }^{\circ} \mathrm{C}\right)$, precipitação pluviométrica (mm)' e umidade relativa (\%) durante - o ano de 1984. Areia, PB, 1985.

\begin{tabular}{|c|c|c|c|}
\hline Meses & $\begin{array}{c}\text { Temperatura } \\
\left({ }^{C} \mathrm{C}\right)\end{array}$ & 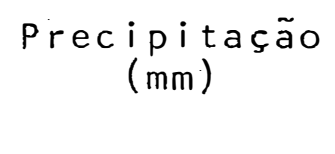 & $\begin{array}{c}\text { Umidade } \\
\text { relativa } \\
(\%)\end{array}$ \\
\hline Janeiro & 24,7 & 41,6 & 69 \\
\hline Fevereiro & 25,2 & 36,6 & 67 \\
\hline Março & 25,1 & 182,2 & 74 \\
\hline Abril & 23,1 & 223,7 & 85 \\
\hline Maio & 22,2 & 220,8 & 86 \\
\hline Junho & 21,8 & 112,0 & 84 \\
\hline Jultho & 21,0 & 174,9 & 85 \\
\hline Agosto & 21,1 & 168,8 & 86 \\
\hline Setembro & 22,1 & 55,2 & 83 \\
\hline outubro & 22,9 & 92,1 & 78 \\
\hline Novembro & 24,2 & 35,8 & 70 \\
\hline Dezembro & 25,4 & 5,0 & 67 \\
\hline
\end{tabular}




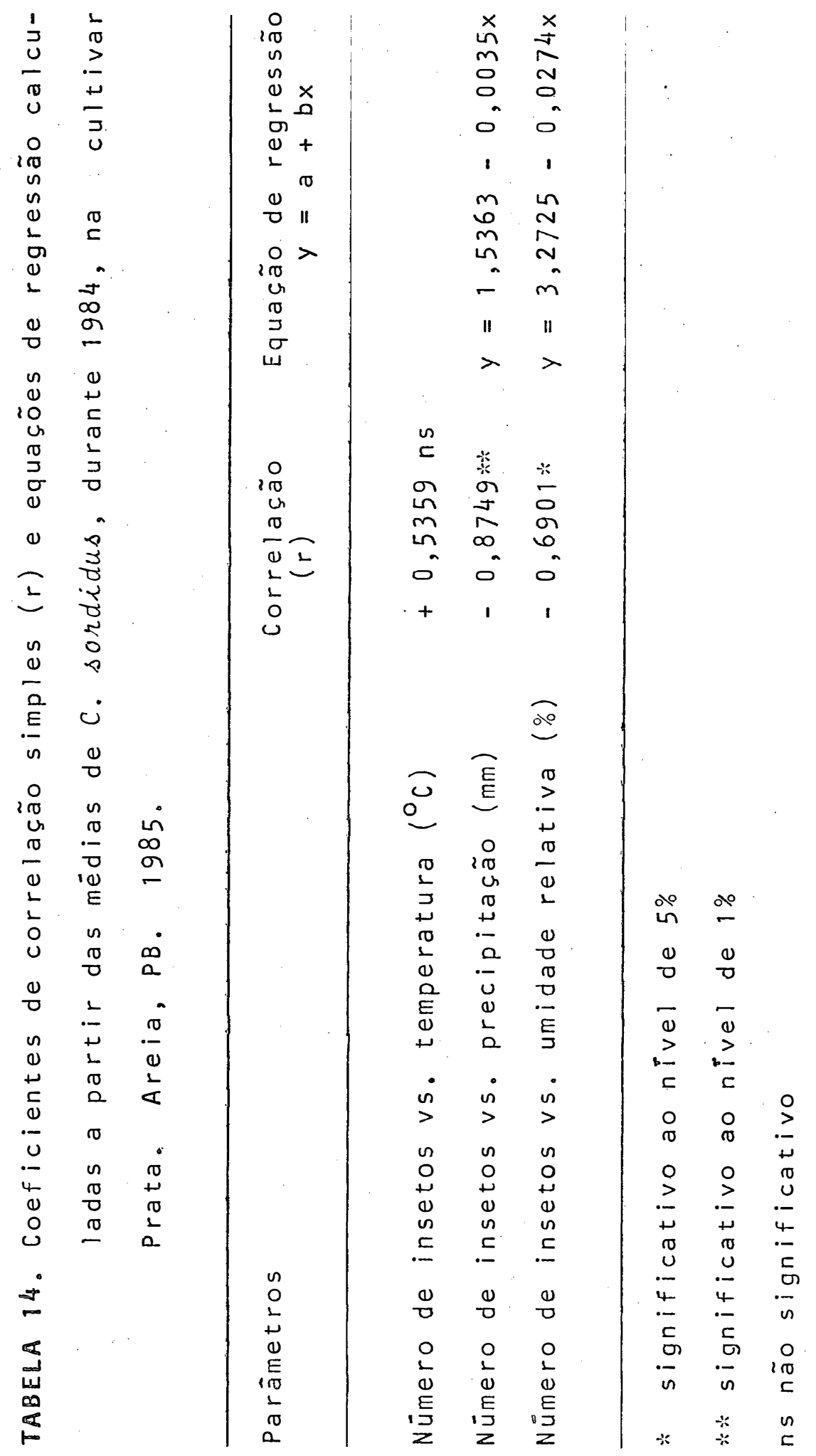


.54.
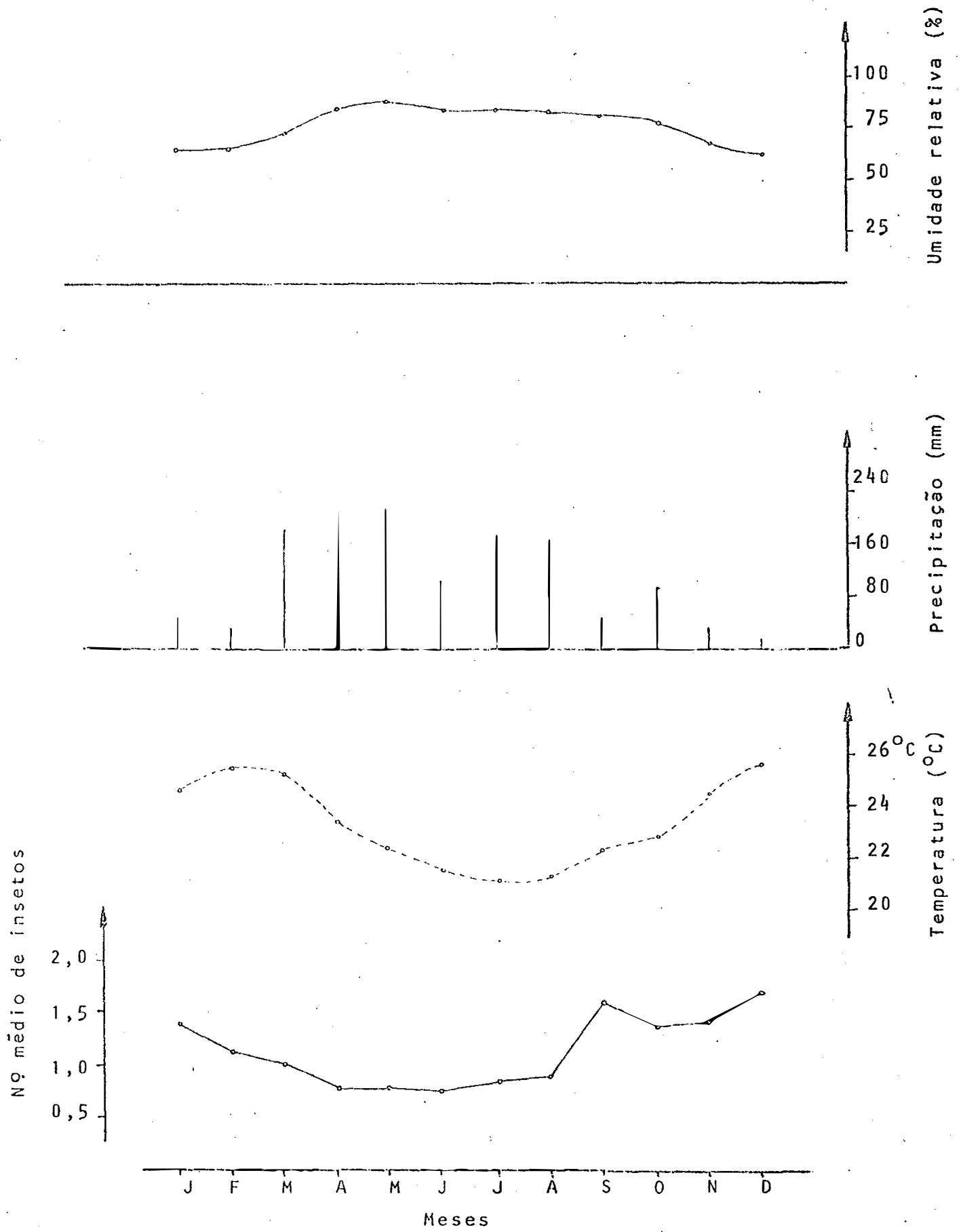

FIgURA 4. Flutuação populacional de C. sordidus e fatores. climáticos. Areia, PB. 1984. 


\subsubsection{Parasitismo natural}

Atravēs dos dados de flutuação pode-se detérminar a p'ercentagem de parasitismo natural de $C$. sordidus pe Io fungo entomógeno Beauvería bassiana na região em estudo.

Durante um ano de coleta, foram capturados 206 adultos, sendo que $0,97 \%$ encontravam-se parasitados.

4.4. Patogenicidade de B. bassiana em adultos de C. sordi dus

Nas Tabelas 15 e 16 são apresentados os resul tados dos contrastes entre as médias, avaliados pelo teste de Tukey, com os dados transformados em $\sqrt{x+0,5}$ e a análise de variància, na qual f foi significativo ao nível de $1 \%$ de probabilidade, obtidos com o número de adultos de $C$. sordidus mortos após o tratamento com suspensão de esporos do fungo $B$. bassiana.

Por estes resultados, observou-se que todos os mëtodos de inoculação de esporos do fungo causaram mortalidade e que estatísticamente não diferiram entresi. Isto demonstra a possibilidade da utilização deste agente entomopatogênico como meio de controle integrado.

Portanto, hä indicações dé que esta praga é 


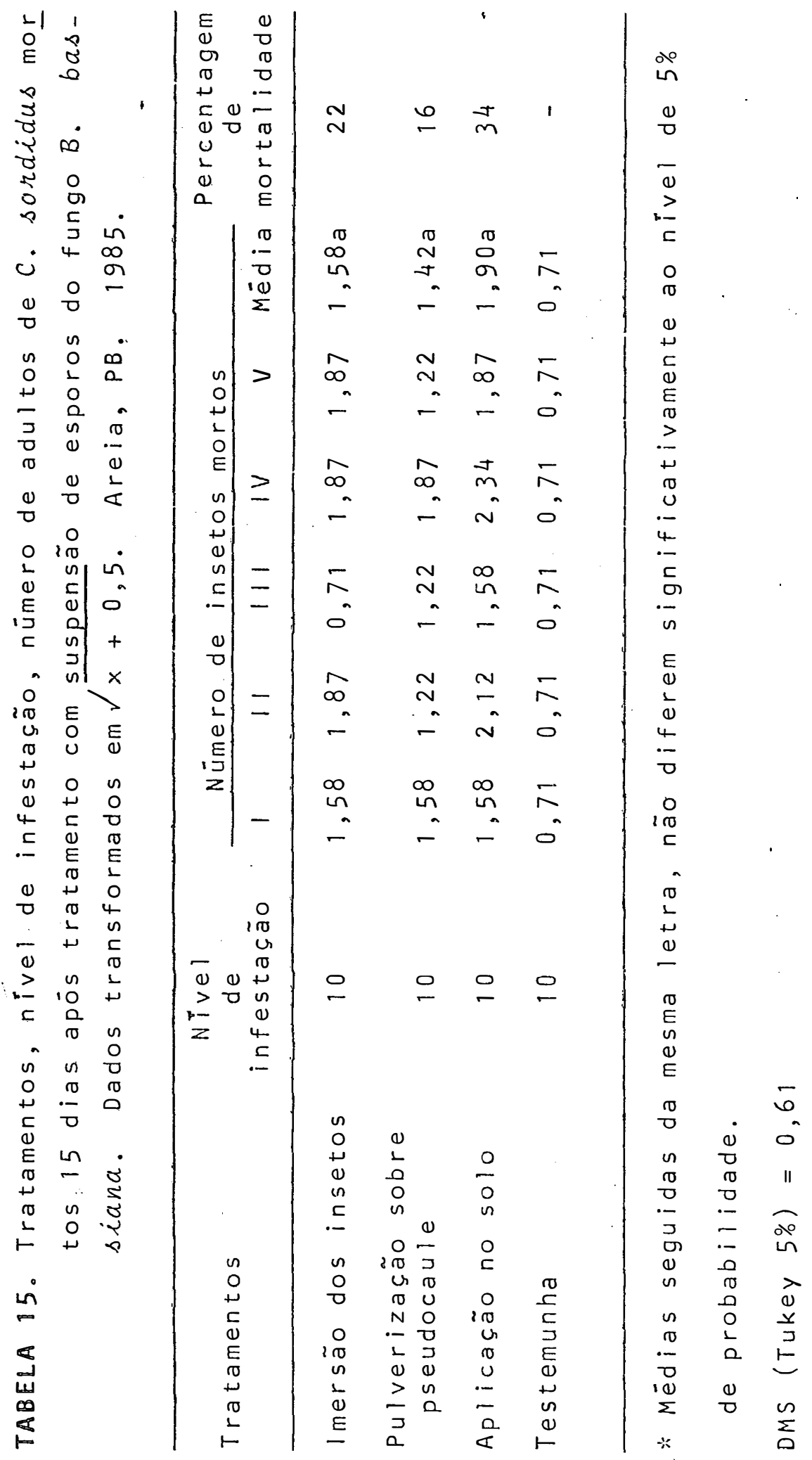


.57.

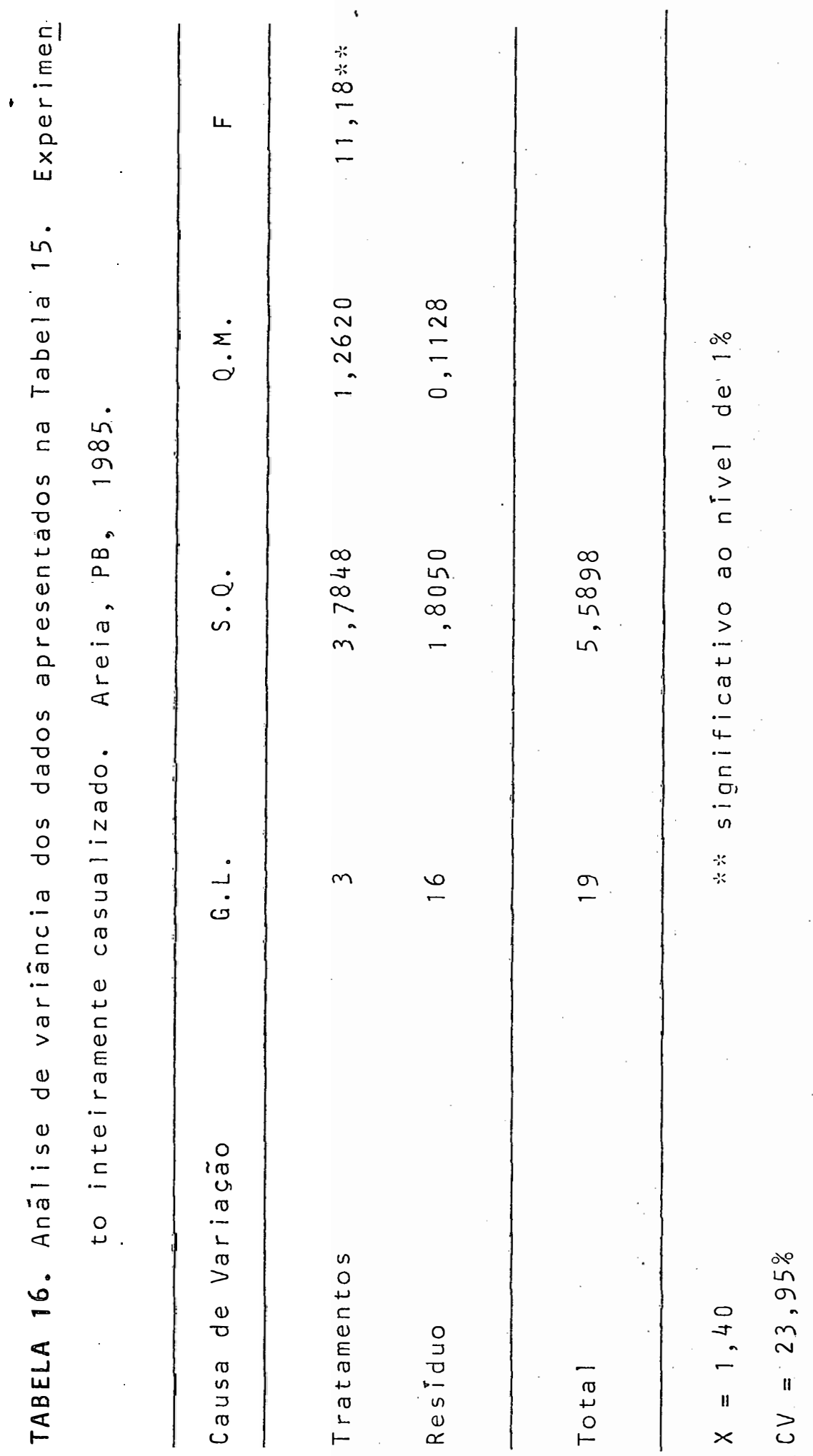


.58.

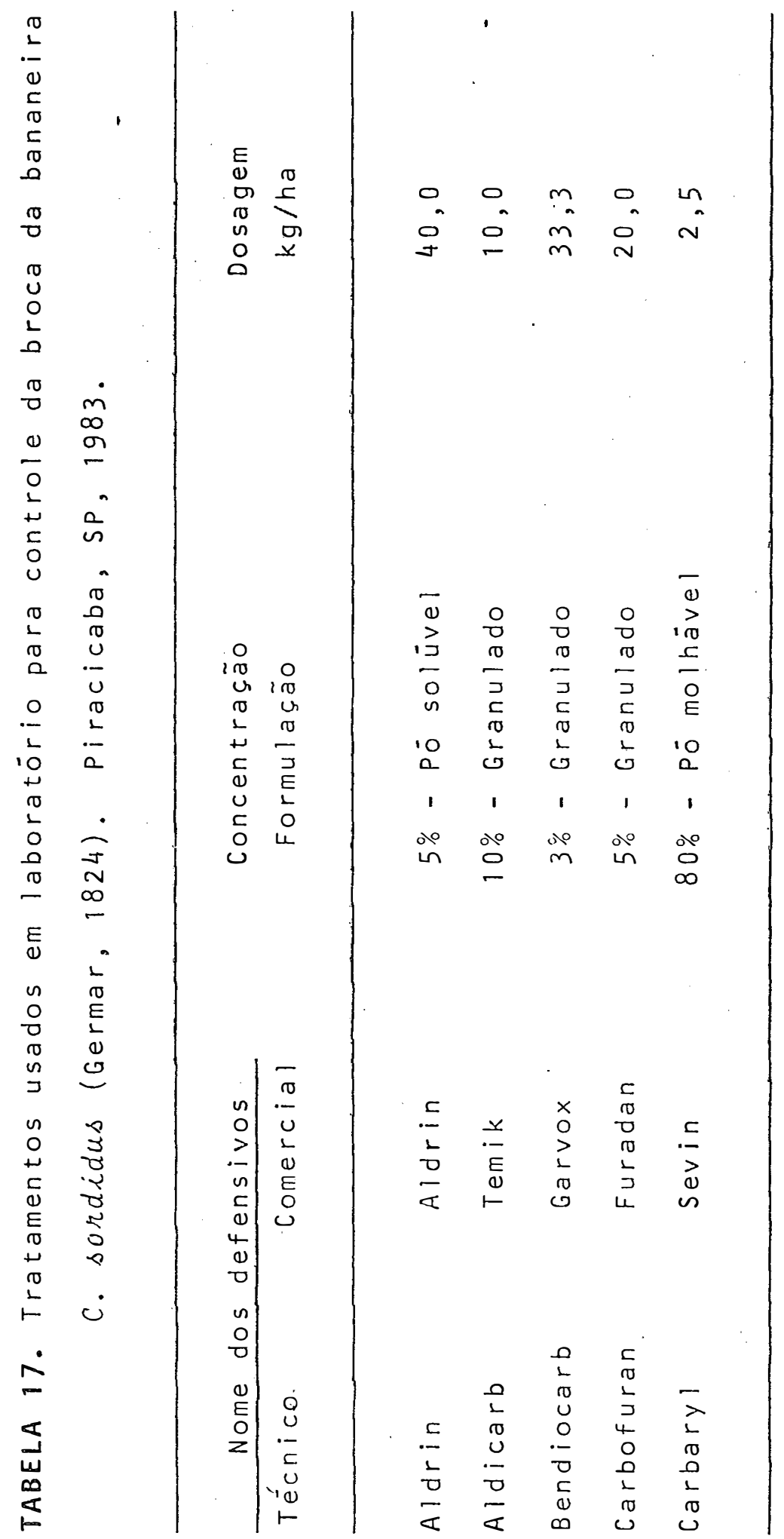


facilmente afetada por este fungo, confirmando os dados de DELATTRE e JEAN BART (1978).

\subsection{Controle químico}

\subsubsection{Estudo comparativo entre produtos clorado}

e carbamatos

os resultados deste ensaio, são apresentados respectivamente nas Tabelas $18,19,20$ e 21 as quais mostram as percentagens de eficiência dos produtos, calculados pela förmula de Abbott, as médias em percentagem transformadas em arc sen $\sqrt{\mathrm{P} / 100}$, e os contrastes entre as médias avaliados pelo teste de Tukey e as anālises de variáncia, nas quais $F$ foi significativo ao nível de $1 \%$ de probabilidade.

os dados obtidos neste ensaio relativos ao pe riodo de 24 horas, mostram que os produtos testados. diferem estatísticamente quanto à eficiência (Tabela 18 e 19). Assim, aldicarb e carbofuran, são os mais eficientes no contro le da praga, seguido do bendiocarb enquanto o carbaril e o aldrin apresentam pouca eficiência.

Contudo, observando-se as Tabelas 20 e 21 (da dos de 48 horas) verificou-se que o aldicarb continua o mais 
.60.

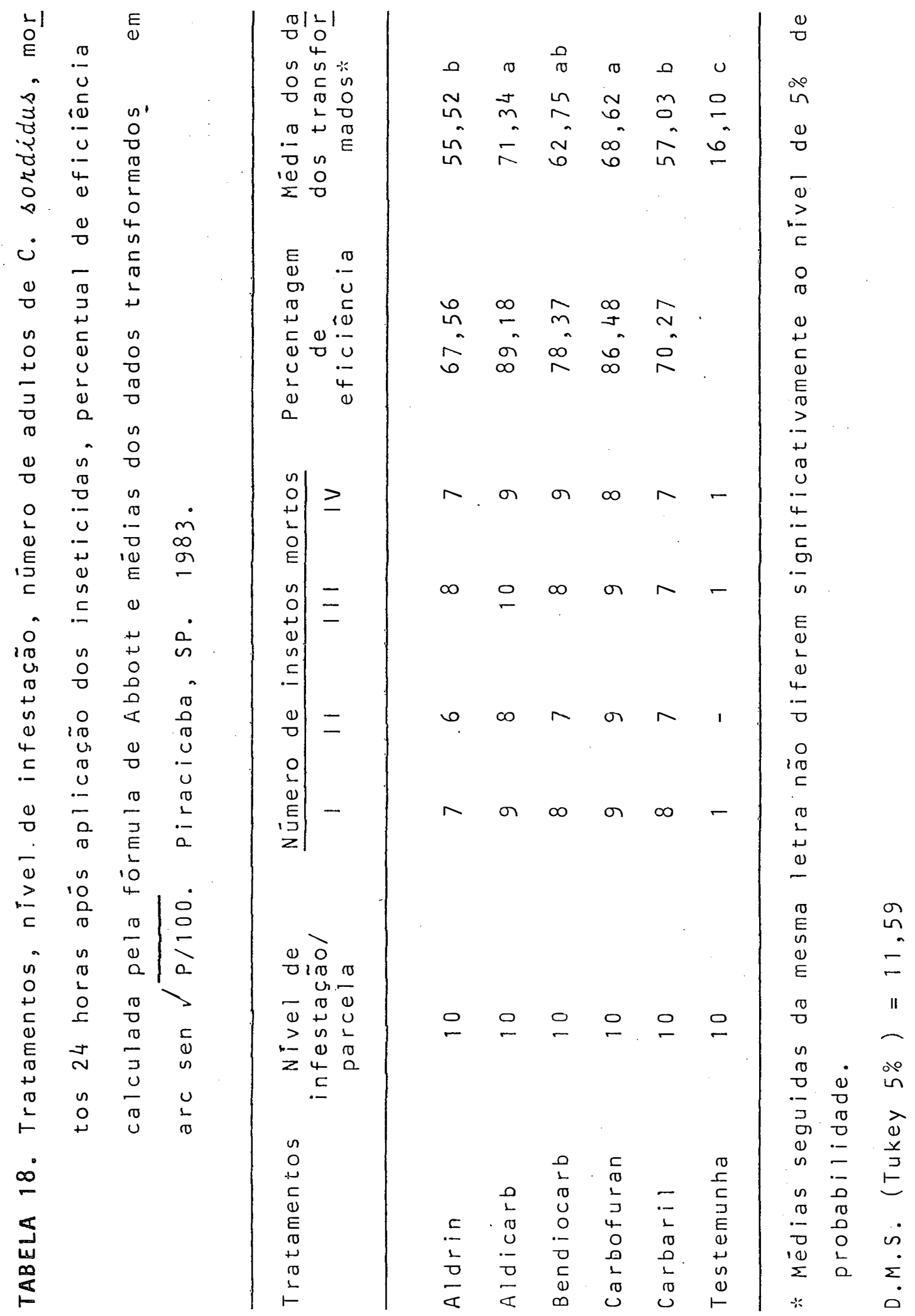


.61.

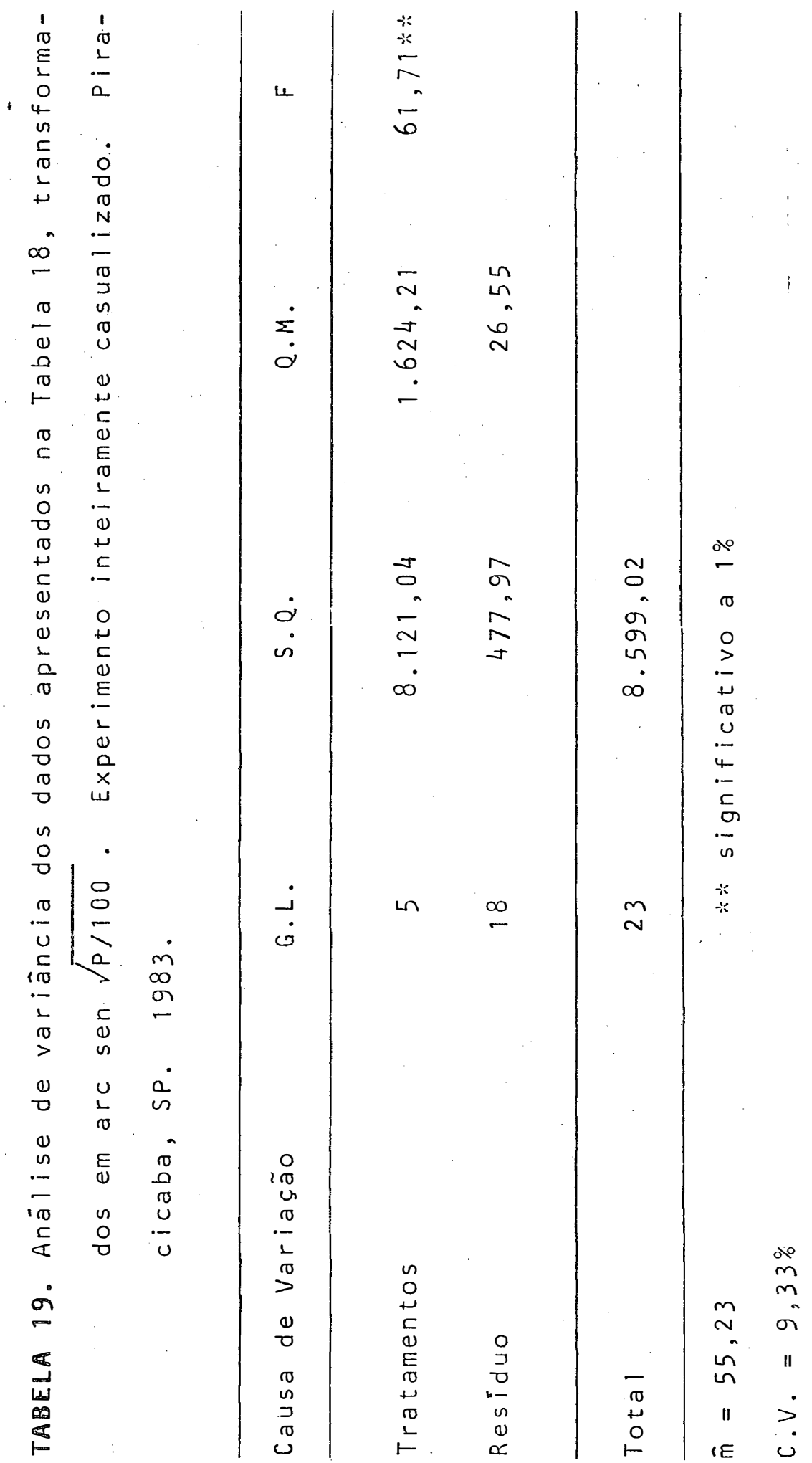


.62.

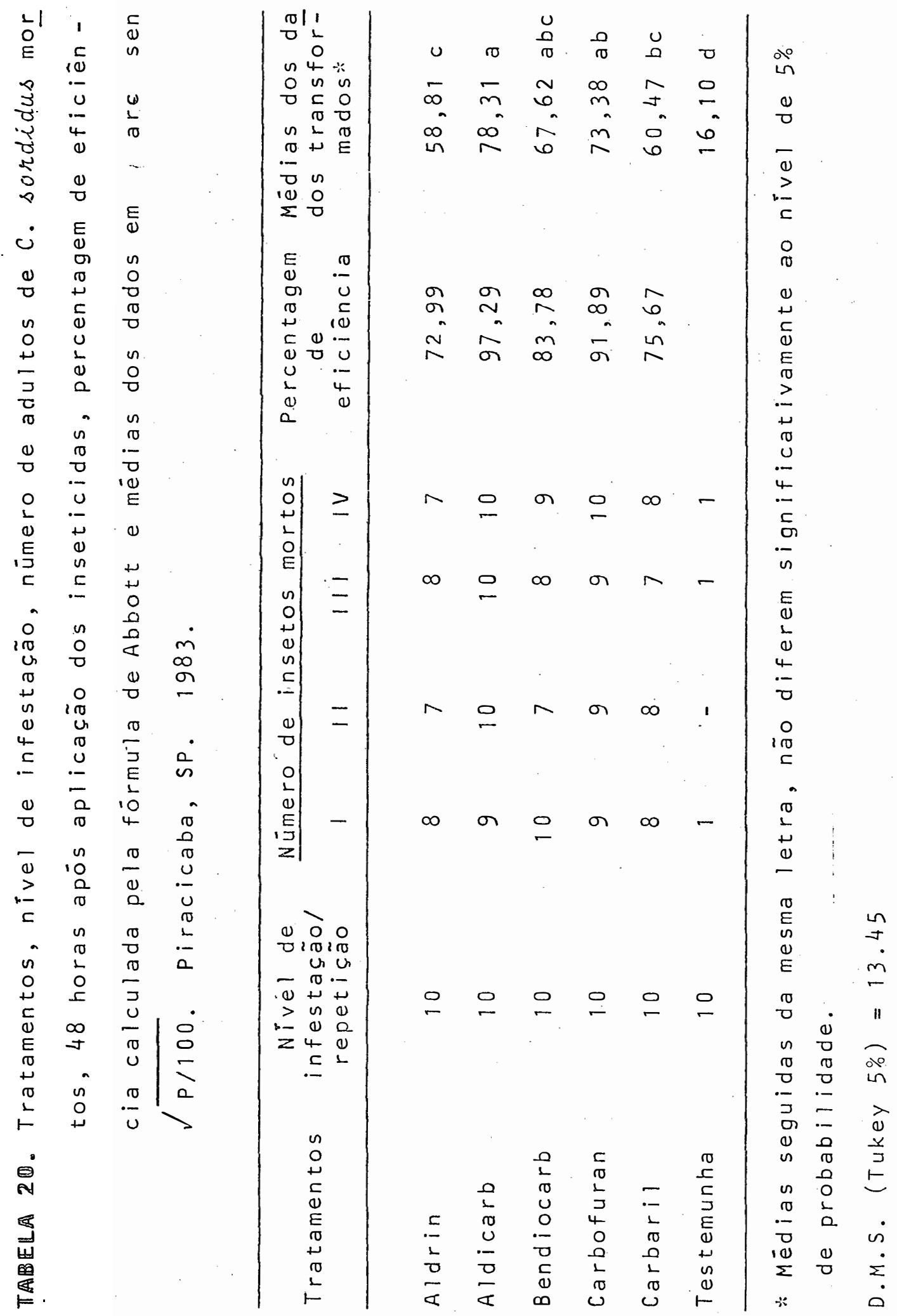


.63.

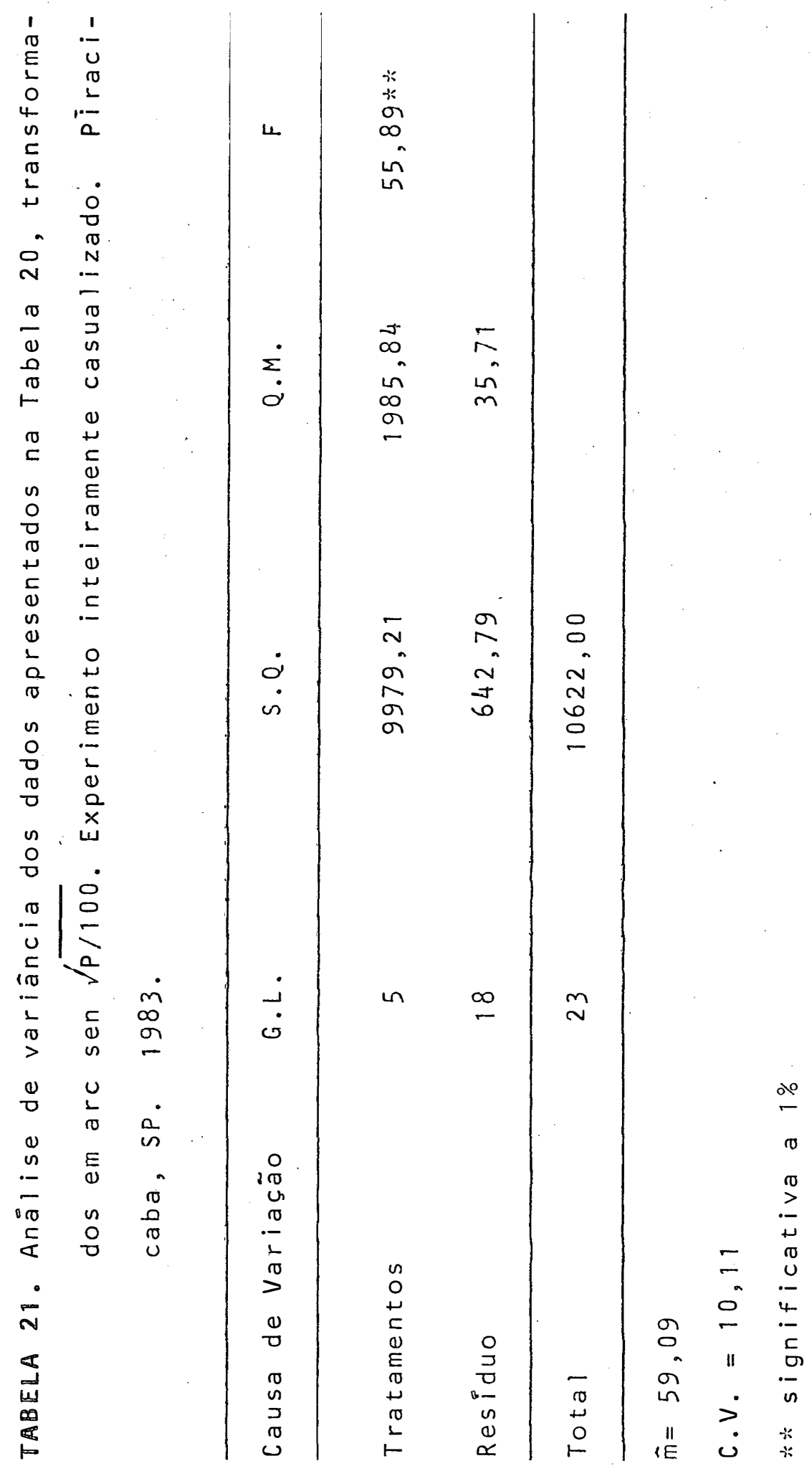


eficiente no controle da praga, seguido pelo carbofuran e bendiocarb, sendo o carbaril e aldrin os menos eficientes.

A boa eficiência encontrada para os produtos aldicarb”e carbofuran confirmam as recomendações de ZEM e ALVES (1979b), MELLO et alii (1979), SAMPAIO et a $i$ i (1980) e ZEM et aZii (1981).

4.5.2. Uso de quimioesterilizantes

Observando-se a Tabela 22 , com o nümero acumu lado de ovos e a percentagem de eclosão nos períodos estudados, verificou-se a alta eficiéncia do diflubenzuron $25 \%$ PM nas dosagens $5,0 \mathrm{~g}$ e $1,25 \mathrm{~g}$ seguida do exicloreto de cobre $50 \%$ PM na dosagem de $20,0 \mathrm{~g}$ e methoprene 5\% CE na dosagem $5,0 \mathrm{ml}$.

Estes resultados confirmam SCHROEDER et ali (1976), CALKINS et alii (1977), OTTENS e TODD (1979), onde estes últimos concluíram que a partir de 75 ppm o diflubenzü ron causou completa inibição da eclosão, nos insetos testados.

De acordo com PELEG e GOTHILF (1981) o methoprene causou inibição no desenvolvimento das cochonilhas Saissetia oleae ( $01 \mathrm{ivier}$ ) e Ceroplastes floridensis Comstock 
.65.

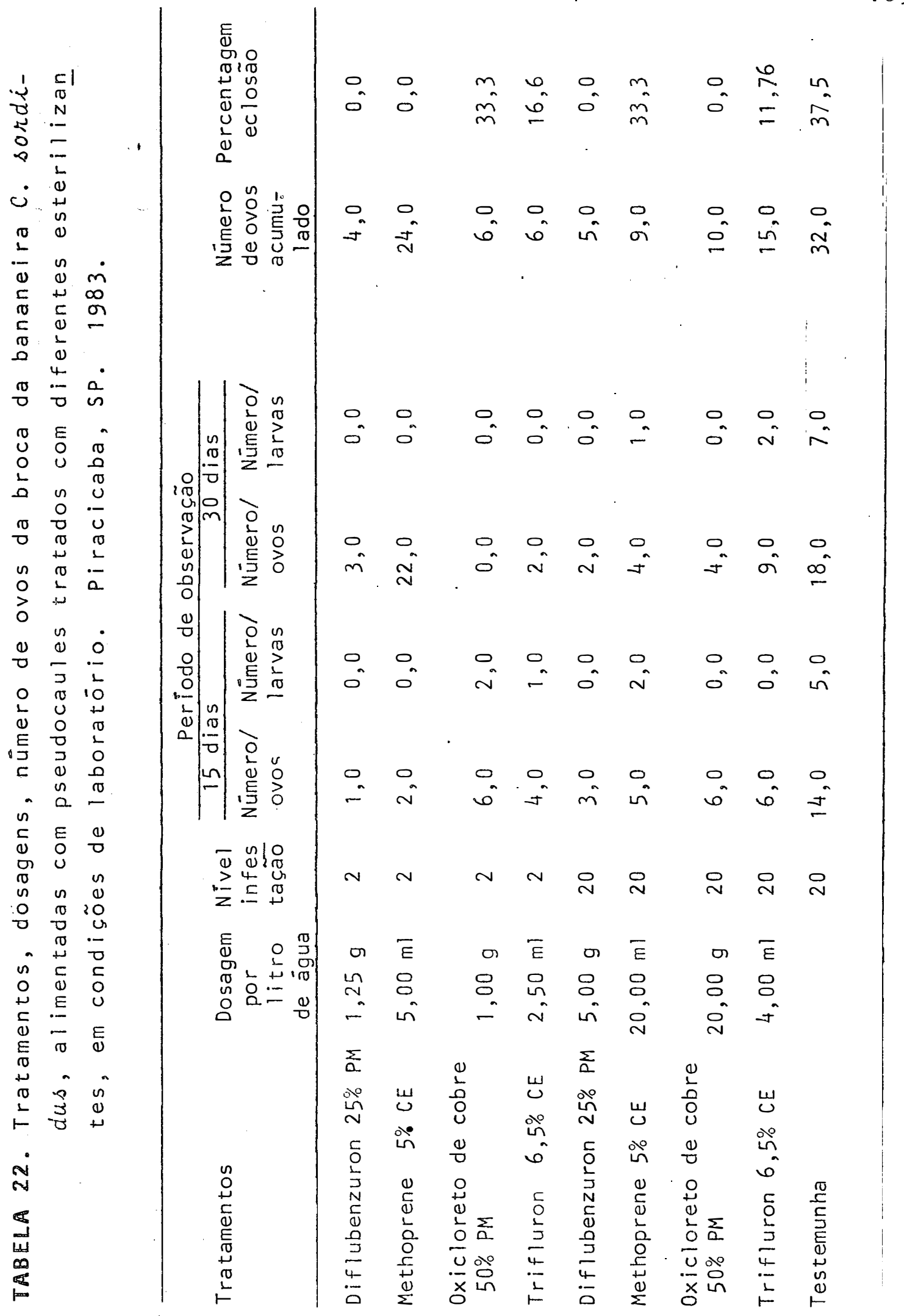


.66.

nas dosagens 0,015 e $0,03 \%$, respectivamente; o mesmo acontecendo para os tratamentos contendo oxicloreto de cobre para moscas das frutas, segundo SALGADo (1979).

Com relação ao tratamento methoprene 5\% CE, observou-se que o aumento da dosagem embora tenha reduzido o nümero de ovos, permitiu a eclosão de larvas. Por outro lado, no tratamento com oxicloreto de cobre 50\% PM na dosagem 1,0 g pode-se verificar que nos primeiros 15 dias. não houve diferença em relação a testemunha, porém no período de 30 dias verifica-se a completa inibição da eclosão.

Quanto ao tratamento com o trifluron $6,5 \%$ CE dosagens elevadas $(4,00 \mathrm{ml})$ ocasionaram inibição temporária da eclosão e na dosagem de $2 \pi, 50 \mathrm{ml}$ registrou-se a inibição da eclosão, confirmado por CHIN CHANG (1979).

Através dos dados registrados na Tabela 23 com dosagens crescentes de avermectin verificou-se que os in setos alimentados com iscas contendo esse produto nas dosagens de 2,8 e $4,2 \mathrm{ml}$ permaneciam fecundos e férteis no 15 ? dia após o tratamento.

Pelos resultados obtidos neste ensaio pode-se observar que durante 30 e 45 dias, os tratamentos com avermectin 4,2 ml e 5,6 ml conferiram inibição da eclosão durante todo o período. Após 60 dias do início dos tratamentos, estudos anatómicos realizados nos ovários de fêmeas adultas 
.67.

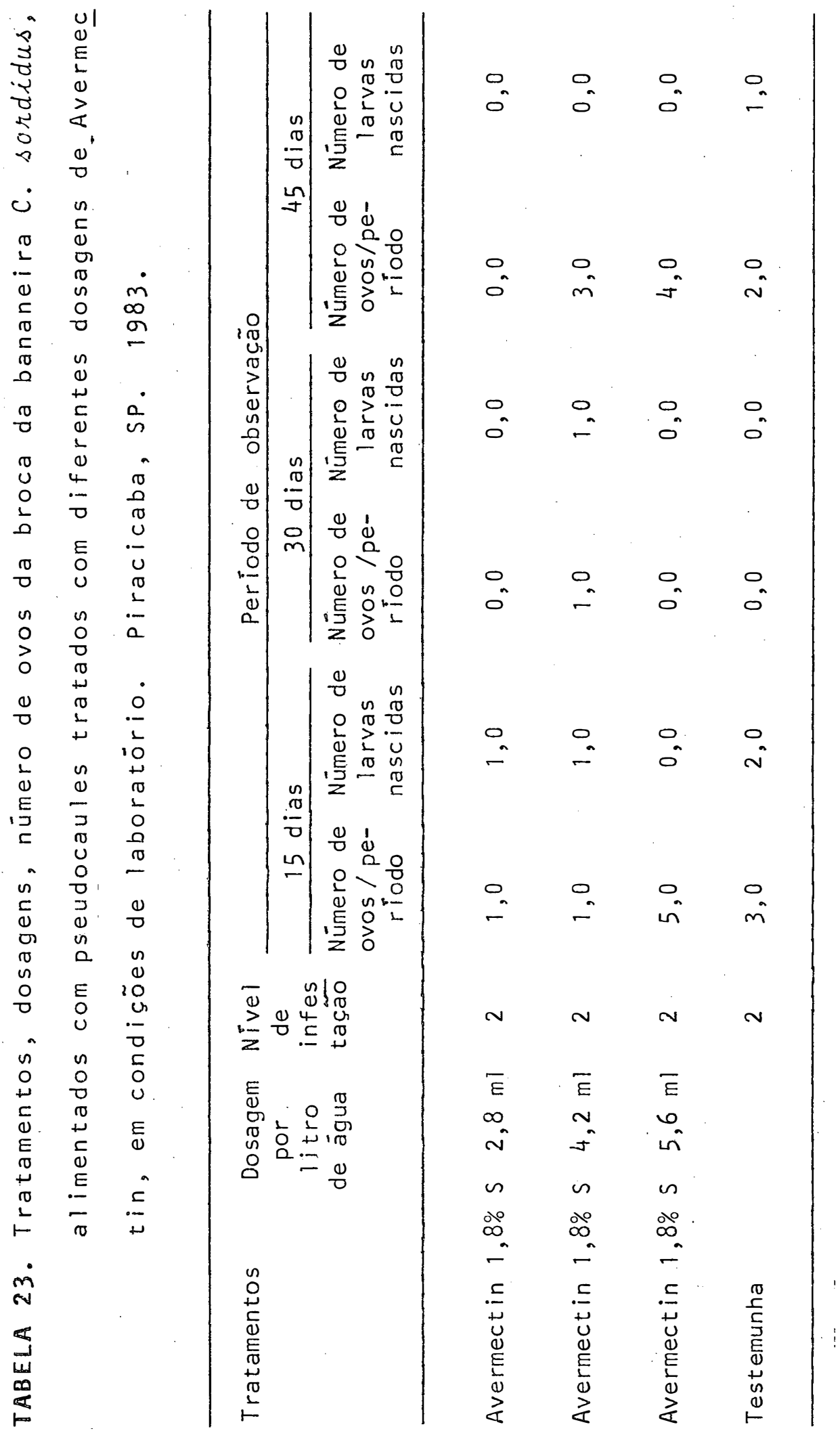


de C. sordidus demonstraram que os produtos considerados esterilizantes não afetaram aparentemente a estrutura e a formação dos óvulos.

Entretanto, a existência de ovos inviāveis è uma indicação segura de que alguma anormalidade deve ter ocorrido por ocasião da formação de ovos. Tais dados permitem concordar com àqueles obtidos por LOFGREN e WILLIAMS (1982) e GLANCEY et alii (1982). 


\section{CONCLUSÓES}

Com base nos resultados obtidos na presente pesquisa pode-se concluir que:

1. Não hà diferença de atratividade entre a isca a base de pseudocaule e rizoma, para a broca da bananeira.

2. A idade do material vegetal interfere na atratividade, sen do que plantas mais jovens são menos atrativas.

3. Os älcoois e melaços não aumentam a atratividade das is cas.

4. Os adultos são sedentārios e sua movimentação dá-se atravès do caminhamento.

5. 0 termopreferendo de $C$. sordidus estä entre 20 e $30^{\circ} \mathrm{C}$.

6. 0 ciclo biolögico de $C$. sordidus sob condições de labora- 
tōrio foi o seguinte: período de incubação variou entre 3 a 12 dias, com uma média de $6,94 \pm 0,63$ dias; período larva.l de 25 a 30 dias com uma média de $27,40 \pm 0,81$ dias e o periodo pupal de 9 a 11 dias, com uma média de $10,33 \pm 0,67 \mathrm{dias}$.

7. Em relação a flutuação populacional de C. sordidus, em Areia, PB, brejo paraibano, nos meses de setembro a dezembro, ocorreu maior atividade dos adultos.

8. Hả tendência de decréscimo da movimentação de $C$. sordidus durante o período chuvoso.

9. O fungo Beauveria bassiana (Bals.) ocorre epizooticamente na população de C. sordidus.

10. A B. bassiana é patogênica a C. sordidus através da inoculação por imersão, aplicação direta no solo ou tratamento do alimento.

11. Os inseticidas aldicarb e carborufan foram eficientes no controle da praga, seguido do bendiocarb.

12. Os produtos diflubenzuron $25 \%$ PM $(1,25 \mathrm{~g}$ e $5,00 \mathrm{~g})$ e o oxicloreto de cobre $50 \%$ PM $(20,00 \mathrm{~g})$ conferem inibição 
.71.

da eclosão para larvas de $C$. sordidus, o mesmo ocorrendo com o avermectin $1,8 \%$ S na dosaçem 5,6 $\mathrm{ml}$, através do preparo do ingrediente ativo por litro de água. 


\section{Literatura CitAada}

ARLEU, R.J., 1982. Dinâmica populacional e controle do Cosmopolites sordidus (Germ., 1824) e Metamasius hemipterus L., 1764 (Col.: Curculionidae), em bananais da cv. Prata, no Espírito Santo. Piracicaba, ESALQ/USP, 55 p. (Tese de Mestrado).

BARTLETT, M.S., 1947. The use of transformations. Biometries. Releigh, 31: 39-52.

BATCHELDER, C.H., 1954. Experimentos con inseticidas para combatir el picudo negro (Cosmopolites sordidus Germ.) en las plantaciones di abacá. I'urrialba, 4․, (2): 88-93.

BECCARI, F., 1967a. Contributto alla conoscenza del Cosmopó. lites sordidus (Germ.) (Coleoptera - Curculionidae). Rivista de Agricoltura subtropicale e tropicale, Firenze, 61 $(1 / 3): 51-93$. 
BECCARI, F., 1967b. Contributto alla conoscenza del Cosmopo lites sordidus (Germar) (Coleoptera - Curculionidae). Ri vista de Agricoltura subtropicale e tropicale, Firenze, $\underline{6} 1(4 / 6): 131-150$.

BULLOCK, R.C. e C. EVERS, 1962. Control of the banana root borer (Cosmopolites sordidus, Germar) with granular insecticides. Tropical Agriculture, London, 39(2): 109-113 .

CALKINS, C.0., A.J. HILL, M.D. HUETTEL e E.R. MITCHELL, 1977. Effect of diflubenzuron on plum curculio populations in laboratory and field tests. Journal of Economic Entomolo gy, Menasha, $\underline{70}(4): 463-466$.

CHAMPION, J., 1968. El Plätano. Barcelona, Editorial Blume, $247 \mathrm{p}$.

CHIN CHANG, S., 1979. Laboratory evaluation of diflubenzu ron, penfluron, and bay, Sir 8514 as female sterilants against the house fly. Journal of Economic Entomology, Menasha, $\underline{72}(4): 479-481$.

CUILLE, J., 1950. Recherches sur le charançon du bananier Cosmopolites sondidus, Germ., Monographie de l'insecte et recherches de ses chimiotropismes. Paris, Institut des Fruits et Agrumes Coloniaux, 225 p. (Ser. Tech., 4). 
.74.

DEBACH, P., 1969. Control Biolögico de las Plagas de Insetos y MaZes Hierbas. México, Continental $949 \mathrm{p}$.

DELÁTTRE; P. e A. JEAN-BART, 1978. Activités des champignons entomapa thogenes (Fungi imperfecti)sur les adultes de Cosmopolites sordidus Germ. (Coleoptera, curculionidae). Turrialba, 28 (1): 287-293.

DELATTRE, P., 1980. Recherche d'une méthode d'estimation des populations du charancon du bananier, Cosmopolites sordidus Germar (Col. Curculionidae). Acta Oecologica, Oecologia Applicata 1(1): 83-92. Apud: Review of Applied Entomology, 69(7): 467, 1981.

EMBRAFA, 1984. Relatório Técnico Anual do Centro Nacional de Mandioca e Fruticultura. Brasillia, Did. 191 p.

FEAKIN, S.D., 1975. Control de las plagas de los bananos. Londres. Center for Orierseas Pest Research, $147 \mathrm{p}$. (Pans Manual, 1)。

FONSECA, J.P., 1936. A broca da bananeira. O Biológico, São Paulo. 2 $2(2): 56-61$.

GAUD, S.M., J.G. TUDURI e L.P. MARTORELL, 1975. Preliminary screening of insecticides for control of banana root borer, Cosmopolites sondidus Germar (Coleoptera-curculionidae). Journal of Agricultural of University of Puerto rico, Rio Piedras, 59(1): 70-80. 
GLANCEY, B.M., C.S. LOFGREN, D.F. WILLIAMS, 1982. Avermectin $B_{1 a}$ effects on the ovaries of red imported fire ant queens (Hym.: Formicidae). Journal of Medical Entomology 19(6): 743-747. Apud: Review of Applied Entomology, 71 $(4): 288,1983$.

HORD, H.H.V. e R.S. FLIPPIN, 1956. Studies of banana weevils in Honduras, Journal of Economic Entomology, Menasha, $49(3): 269-300$.

LICERAS, L., R. URRELO e S.BELTRAN F., 1973. Ensayo para el control del gorgojo negro del plátano, Cosmopolites sordi dus Germar (Coleoptera-Curculionidae), al momento de la siembra. Revista Peruana de Entomologia, Lima, 16(1): 50 -54 .

LOFGREN, C.S. e D.F. WILLIAMS, 1982. Avermectin Bia, a highly potent inhibitar of reproduction by queens of the red imported fire ant. Journal of Economic Entomology, Menasha, $\underline{75}(5): 798-803$.

LONGORIA, G.A.G., 1975. Dimorfismo sexual observado en pupas de Cosmopolites sordidus Germar (Coleoptera-Curculionidae). Ciência Sërie 11 Sanidade Vegetal, La Habana, n. 6. $6 \mathrm{p}$. 
MARTINEZ, J.A., 1971. Flutuações da população da broca-da- bananeira moleque (Cosmopolites sordidus Germar). In: Anais do Congresso Brasileiro de Fruticultura, Campinas, Sociedade Brasileira de Fruticultura, V. I, p. 187-194.

MATTOS, J.R. e S. SIMÃO, 1967. A broca da bananeira (Cosmopolites sordidus Germ) na interplantação de bananais. Re vista de Agricultura, Piracicaba, 42(1): 15-17.

MELLO, E.J.R. e R.H. MELLO, 1975. Constatação de resistência ao aldrin em adultos de Cosmopolites sordidus, broca. da bananeira. Ciência e Cultura, São Paulo, 27(7): 607-oub.

MELLO, R.H., E.J.R. MELlo e J.A. MARTINEZ, 1979. Eficiência de iscas envenenadas sobre a broca da bananeira ou mo leque (Cosmopolites sordidus Germ.). In: Anais do V Congresso Brasizeiro de Fruticultura, Pelotas, Sociedade Bra sileira de Fruticultura, v. 2. p. 672-680.

MELLO, E.J.R., R.H. MELLO e N. SUPLICY FILHO, 1980. Ensaios de laboratório para verificar a ação de inseticidas granu lados e carbamatos sobre brocas da bananeira resistentes ao aldrin. O Biozógico, São Paulo, 46(7): 141-144.

MESQUITA, A.L.M., E.J. ALVES e R.C. CALDAS, 1984. Resistance of banana cultivars to Cosmopolites sordidus (Germar 1824) Fruits, Paris, 39(4): 254-257. 
MILLER, J.A., S.E. KUNZ, D.D. OEHLER e R.W. MILLER, 1981. Larvicidal activity of Merck MK-933, an avermectin, against the harn fly, stable fly, face fly and house fly. Journal of Economic Entomology, Menasha, 74(5): $608-$ $-611$

MOORE, R.F., R.A. LEOPOLD e H.M. TAFT, 1978. Boll weevils: mechanism of transfer of. diflubenzuron from male to female. Journal of Economic Entomology, Menasha, $71(4)$ : $587-590$.

MOREIRA, R.S., 1971. A broca das bananeiras. Correio Agricola, São Paulo, (1): 10-12.

MOREIRA, R.S., 1979 a. A broca das bananeiras (Cosmopolites sordidus Germ.). Seu combate. In: Anais do V Congresso Brasileiro de Fruticultura, Pelotas, Sociedade Brasileira de Fruticultura, v. 2, p. 642-649.

MOREIRA, R.S., 1979b. Bananais livres de broca produzem o dôbro. Correio Agrícola, São Paulo, (2): 202-206.

MOREIRA, R.S., 1984. Bananas sem "moleque" são mais produt vas. Informativo da Sociedade Brasileira de Fruticultura, $\underline{3}(2): 10-12$.

NANNE, H.W. e J.W. KLINK, 1975. Reducing banana root weevil adults from an established banana plantation. Turrialba, $\underline{25}(2): 177-178$. 
NOGUEIRA, S.B., 1975. Efeito de alguns inseticidas, alcoois e èster aplicados em isca contra a broca da bananeira, Cos mopolites sordidus, Metamasius ensirostris e Metamasius inaequalis (Coleoptera-curculionidae). Viçosa, UFV, 45 p. (Tese de Mestrado).

NOGUEIRA, S.B., 1977. Preferência das brocas de bananeiras Cosmopolites sordidus e Metamasius ensirostris (Coleoptera-curculionidae) por 10 diferentes cultivares de banane ras. In: Resumos do IV Congresso Brasizeiro de Entomozogia, Goiảnia, Sociedade Entomologica do Brasil, p. 108 .

OLIVEIRA, A.M., S. SUDO, D.F. BARCELLOS, G. MENDES, W. MAIOLINO e N. do A. MENEguelLI, 1976. Flutuação da população do Cosmopolites sordidus e Metamasius spp., em bananais de Angra dos Reis, Estado do Rio de Janeiro. Pesquisa Agropecuāria Brasizeira, Sërie Agronomia, Rio de Janeiro, $11(2): 37-41$.

ÒTTENS, R.J. e J.W. TODD, 1979. Effect of diflubenzuron on reproduction and development of Graphognathus peregrinus and G. leucoloma. Journal of Economic Entomology, Menasha, $\underline{72}(5): 743-746$.

PELEG, B.A. e S. GOTHILF, 1981. Effect of the insect growth regulators diflubenzuron and methoprene on scale insects. Journal of Economic. Entomology, Menasha, 74 (1): $124-126$. 
.79.

PULLEN, J., 1973. The control of the banana weevil (Cosmopo lites sordidus Germ.) in Latin America an The Caribbean With pirimiphos ethyl. Pans, London, 19(2): 178-181.

ROBERTS, F.S., 1955. The banana root borer lCosmopolites sordidus Germ.). La Lima, United Fruit Company, $11 \mathrm{p}$.

ROTH, L.M., E.R. WILLIS, 1963. The humidity behavior of Cosmopolites sordidus (Coleoptera-eurculionidae). Annals of the Entomological Society of America, College Park, $\underline{56}$ (1): 41-52.

SALGADO, L.0., 1979. Effeito biolögico do oxicloreto de cobre sobre Ceratitis capitata (Wiedmann, 1824) (Diptera: Tephritidae) em dieta artificial. Piracicaba, ESALQ/USP, 116 p. (Tese de Doutoramento).

SAMPAIO, A.S., I. MYAZAKI, N. SUPLICY FILHO, D.A. OLIVEIRA, 1982. "Broca da bananeira" - Cosmopolites sordidus (Germar, 1824) (Coleoptera, Curculionidae) resistente ao aldrin e seu controle com inseticidas sistemicos aplicados no solo. O Biológico, São Paulo, 48 (4): 91-98.

SARAIVA, A.C., 1964. O gorgulho da bananeira Cosmopolites sordidus (Germar) no arquipēlago de Cabo Verde. Estudos Agronômicos, Lisboa, $\underline{5}(2): 59-65$.

SCHMIDT, C.T., 1965. O gorgulho da bananeira em São Tomé. Estudos Agronômicos, Lisboa, 6(3): 97-103. 
SCHROEDER, W.J., J.B. BEAVERS, R.A. SUTTON e A.G. SELHIME, 1976. Ovicidal effect of Thopmson - Hayward TH-6040 in Diaprepes abbreviatus on citrus in Flörida. Journal of Economic Entomology, Menasha, 69(6): 780-782.

SILVA, P. e J.M. ABREU, 1969. A broca da bananeira na região cacaueira da Bahia. Cacau Atualidade, Itabuna, 6(3/ 4): $22-25$.

SIMMONDS, N.W. e F.J. SIMMONDS, 1953. Experiments on the banana borer, Cosmopolites sordidus, in Trinidad, B.W.I. Tropical Agriculture, Trinidad, $30(10 / 12): 217-223$.

SIMMONDS, N.W., 1966. Bananas. 2a Ed., London, Longmans, $512 \mathrm{p}$.

SIMMONDS, N.W., 1973. Plagas. In: Los Platanos, Tusek, Blu me .

SHANAHAN, G.J. e G.J. GODDYER, 1974. Dieldrin resistance in i Cosmopolites sordidus in New South Wales Austria. Journal of Economic Entomology, Menasha, 67(3): 446.

SOTOMAYOR, B.B., 1972. Resistência de Cosmopolites sordidus Germar, a los compuestos organo clorados en el Equador. Revista Peruana de Entomologia, Lima, 15(1): 169-175. 
TAFT, H.M. e A.R. HOPKINS, 1975: Boll weevils: Field populations controlled by sterilizing emerging overwintered females with a TH-6040 aprayable bait. Journal of Economic Entomology, Menasha, 68(4): 551-554.

VEIGA, A.F.S., J.F. WARUMBY, R.J. MOURA, J.L.A. JONIOR e A. P. DANTAS, 1981. Dinâmica populacional de Cosmopolites sordidus (Germar, 1824), Metamasius hemipterus, e ocorrên cia de epizootias por Beauveria bassiana em plantios da bananeira "prata" situados em topografia de vārzea e " de serra, no estado de Pernambuco. In: Anais do.VI Congresso Brasileiro de Fruticultura, Recife, Sociedade Brasilei ra de Fruticultura, V.1 P. 252-268.

VILARDEBO, A., 1973. Le coefficient d'infestation critère d'èvalution du degré d'attaques des bananeraies par cosmo polites sordidus Germ. le charançon noir du bananier. Fruits, Paris, $28(6): 417-426$.

WRIGHT, W.E., 1977. Insecticides for the control of dieldrin resistant banana weevil borer, Cosmopolites sordidus Germar, Australian Journal of Experiment Agriculture and Animaz Husbrandy, Melbourne, 17(86): 499-504.

YARINGANO, C.V.M. e F. Van Der MEER, 1975. Control del gorgojo del platano, Cosmopolites sordidus, mediante trampas diversas y pesticidas granulados. Revista Peruana de Entomologia, Lima, 18(1): 112-116. 
ZEM, A.C., J.A. ROdRIGUES, E.J. AlVES, 1978: Comportamento de cultivares de bananeiras (Musa spp.) ao ataque da broca do, rizoma (Cosmopolites sordidus Germar) (Coleoptera Curculionidae). Ecosistema, Espirito Santo do Pinhal, 3 $(3): 8-10$.

ZEM, A.C. e E.J. AlVES, 1979a. A broca da bananeira Cosmopo lites sordidus (Germar, 1824) no Estado da Bahia I - Inci dência e movimentação. In: Anais do V Congresso Brasilei ro de Fruticultura, Pelotas, Sociedade Brasileira de Fruticultura, V.1, p. 284-289.

ZEM, A.C., E.J. ALVES, 1979b. A broca da bananeira Cosmopolites sordidus (Germar, 1824) no Estado da Bahia 11 - Tra tamento quimico da muda. In: Anais do V Congresso BrasiZeito de Fruticultura, Pelotas, Sociedade Brasileira de Fruticultura, v. 1, p. 290-294.

ZEM, A.C., J.A.S. RODRIGUES e E.J. ALVES, 1981. Eficiència de inseticidas sistêmicos granulados no controle da broca da bananeira na cultivar Prata. In: Resumos do VII Congresso de Entomologia, Fortaleza, Sociedade Entomologica do Brasil, p. 156. 